\title{
Saint Martin's Diocese: The Appropriation of Episcopal Symbols
}

\author{
Saint Martin's Feast of July 4: \\ Divine Presence, Episcopal Authority
}

When Guibert of Gembloux made his pilgrimage to Tours in I I 80-8 I he brought with him a letter from Archbishop Philip of Cologne, who wished to clarify certain points about the way Saint Martin's cult was observed in Tours. The distance that separated him from Tours prevented Archbishop Philip from learning "your names"-those of the monks of Marmoutier and the canons of SaintMartin, to whom he addressed his letter. ${ }^{1}$ Nevertheless, news concerning the dramatic way the canons at Saint-Martin celebrated Saint Martin's July feast had reached Philip's ears. He found the practice so unusual that he wanted written confirmation of what he had heard:

There are two matters especially that have been conveyed to us by rumor alone, which we vigorously entreat you to confirm in writing. ... The second matter, if it is indeed true, is wondrous and incomparable in our view. For it is said that on the night of the ordination and translation of [Saint Martin] [July 4], after compline has been solemnly sung and the multitude of people turned out of the church, the doors of the church in which he corporally rests are carefully closed, all the instruments necessary for the mass are left on the altar, and no mortal is allowed to enter there until dawn. And the tradition accepted by most people-and held by yourselves to be confirmed by miracles-is that on that night and in that very church the divine office is celebrated by the blessed pontiff along with other saints. About this

I. "Itaque nomina vesta propter distantiam nobis quidem incognita" (excerpt from MS. 428-42, fols. I I Ir-I I 2v, Bibliothèque Royale Albert I, Brussels, printed in Catalogus codicum hagiographicorum . . Bruxellensis, $\mathrm{I}: 532-34$ [the quoted passage is on p. 534]). There is a new edition of this letter in Guibert, Abbot of Gembloux, Guiberti Gemblacensis epistolae, 60-63. My references are to the old edition. 
matter, which is so stupendous and unusual in everyone's eyes . . . we would like you to certify by which experience it is known, by which authors it has been publicized, and by what signs it has been proved. 2

In their response to Archbishop Philip, Philip and Renaud, the dean and treasurer of Saint-Martin, assured him that much of what he had already heard was accurate. It was on the night of July 3, the vigil of Martin's July feast, that the canons at Saint-Martin observed the custom of emptying the basilica so that Martin and his saintly entourage could occupy it. The canons did not put out preparations for the mass, however, because "the spirits and souls of the saints have no need for those things." Still, Philip and Renaud left open the possibility that Martin may have dressed himself in his old liturgical vestments, since the canons still held these in their possession:

After all the people, both citizens and pilgrims, have been sent outside with diligent care, we concede the same basilica, which is radiant with a number of torches and with candles that shine in coronas, to God and to its blessed possessor and to the other saints. And . . the most notable members of our convent-the dean, treasurer, cantor, magister scholarum and cellarer-assign . . two watchmen for each door of the temple, in addition to... [the six custodians who are always there]. In answer to your question, we put out on the altar no necessary preparations for the mass, because we know that the spirits and souls of the saints have no need for these things for the divine services. Nevertheless, we know that the sacred vestments that the great priest used in his days for the celebration of the sacraments are concealed in a secret place known to only a few, next to his tomb. ${ }^{3}$

2. "Duo maxime sunt, super quibus, cum ad nos ex sola fama perlata sint, ex scriptis vestris certificari obnixe exposcimus. . . . alterum, quod si verum est, mirabile immo incomparabile est in oculis nostris: siquidem fertur quod in nocte festi ordinationis seu translationis ejus, cantato solemniter completorio et conflua populi multitudine ejecta, januae omnes ecclesiae in qua corporetenus requiescit, diligenter claudantur, omnis missae necessarius altari apparatus adhibeatur, nullus mortalium usque ad ortum solis ingredi permittatur: eo quod et a majoribus traditum et etiam miraculis confirmatum apud vos teneatur, ipsa nocte in eadem ecclesia a beato pontifice sanctisque aliis divina celebrari. Super qua re tam stupenda cunctis et insolita, qua vobis experientia comperta, quibus auctoribus propalata, quibus signis comprobata sit ... certificati fuerimus" (Catalogus ... Bruxellensis, I:240-4I).

3. "Omnibus tam civibus quam peregrinis diligenti cura eliminatis, eamdem basilicam, cereis super coronas fulgentibus radiantem et pluribus coruscantem lampadibus, Deo beatoque ejus possessori et sanctis aliis concedimus, insignioribus personis conventus nostri, decano videlicet, thesaurario, archicantore, scholarum magistro et cellerario, singulis templi januis . . . duobus excubitoribus . . . assignantibus, praeter illos xii qui ex instituto seni et seni alternis vicibus perenniter templi ejusdem solvunt custodiam. Apparatum vero missae necessarium altari, ut quaeritis, nullum apponimus, spiritus et animas 
This striking ritual was described again in the customal of SaintMartin, written after I226. Unlike Philip and Renaud, however, the customal specified that the canons did put out materials for the massbread, wine, a chalice, and a censer of incense. 4

The ritual, and the supernatural presence it publicized, called attention to several themes discussed in chapter 7. First, like the celebration of the May feast-when Châteauneuf became a "paradise"- the July vigil suggested that at a particular time of year a particular place underwent a supernatural transformation. Saint Martin was always the "possessor" of the basilica where his relics resided, but on one day especially he and his entourage took possession of it. Like the city, the basilica underwent the alternation of secular times and sacred times, which corresponded in a predictable manner to certain feast days. This temporal emphasis was quite different from that of Marmoutier, where the rhythm of ghostly and saintly visitations corresponded to the rhythm of life and death rather than that of predictable calendrical times. 5

The July ritual, and Philip and Renaud's recounting of it, also illustrated the importance the canons gave to material objects and display. When they relinquished the basilica to the saintly entourage, the canons left it shimmering with candles and coronas. They were proud that they still possessed Martin's vestments. More important, however, the supernatural visitation, the feast it celebrated, and the ritual that called attention to it all focused on the physical space of the basilica. The feast of July 4 celebrated, in part, the day Martin had been ordained into the priesthood, but it was primarily the celebration of two dedications when his relics were translated into the basilica. On July 4, in the fifth century, Perpetuus dedicated his new church over Martin's tomb, and again on that day in Ior4 Herveus,

sanctorum in divinis obsequiis his scientes non indigere. Sacras tamen vestes quibus sacerdos magnus in diebus suis in celebratione sacramentorum utebatur, in loco secreto et paucis cognito juxta mausoleum ejus scimus esse reconditas" ("De cultu Sancti Martini apud Turonenses extremo saeculo XII," 227).

4. Consuetudines ecclesiae beati Martini, 78. (On the date of the customal, see Source Appendix, II-B.)

5. Most of the visions of Saint Martin in the "De rebus gestis in Majori monasterio" (see Source Appendix, I-D, and discussion in chapter 5 ) occurred at the time of an illness or death. The one exception (17, p. 405), which most resembles Saint-Martin's July visitation, was a vision on the night of All Saints', when a monk saw Martin, Saint Fulgentius, Saint Corentin, and the dead abbots and monks of Marmoutier. Although this story placed some emphasis on a calendrical date, there was no assertion that Martin visited every year at that time (only that he frequently visited), and the date itself made reference to the cycle of life and death and to the need for suff rages for the dead. 
the treasurer of Saint-Martin, dedicated a newer basilica. 6 The feast of July 4 was really a dedication feast, and the fact that Martin took possession of his basilica by visiting it each year demonstrated the special success of the dedication.

On one level the emphasis on impressive display and the belief in Martin's presence in a particular place at a particular time demonstrates, once again, that the canons thought and behaved in ways that mirrored the secular rhythms, material values, and status orientations of their urban neighbors. But though these orientations lay beneath the surface of the July ceremony and the way it was represented, the more manifest message concerned the focused presence of divineand episcopal-power. Martin's annual visitation, accounts of his occasional interactions with mortals who witnessed that visitation, and descriptions of what the witnesses saw served the purpose of illustrating, both to the ordinary laypeople who were ritually excluded from the church one night each year and to the archbishop of Tours, who was always excluded except on the day of his consecration, that divinely ordained episcopal power resided at the basilica. This power rubbed off on the canons, enhancing their claims to independence, dominance, and lordship.

In this chapter and the next I will examine the various ways the canons of Saint-Martin employed and manipulated the ritual calendar of Tours and the cult of Saint Martin to bolster their position vis-à-vis both their archbishop and the burghers of Châteauneuf. In both cases, the second half of the twelfth century and the early years of the thirteenth saw a resurgence of attempts to undermine the jurisdictional rights of the canons: the burghers attempted to form a commune and thus to escape the secular lordship of the canons, and the archbishop of Tours attempted to win back spiritual and temporal rights over religious houses that were subordinated to Saint-Martin.

Before turning in this chapter to the canons' struggles with the

6. On Perpetuus's church and the triple significance of the July feast (Martin's ordination, the dedication of the basilica, and the translation of his relics into it), see Gregory of Tours, Historia francorum, 2:14, p. 64. On the date of Herveus's dedication, see Brevis historia Sancti Juliani Turonensis, 229; Narratio de commendatione Turonicae provinciae, 30I; Oury, "Idéal monastique dans la vie canoniale: Le bienheureux Hervé de Tours," Is.

Early medieval liturgical sources indicate that Martin's July feast was more important at Tours than elsewhere. By the eleventh century the octave of the July feast was observed at Tours with a dedication service: see Oury, "Messes de Saint Martin dans les sacramentaires," 82, 85; Oury, "Culte et liturgie de St. Martin"; Tours, Bibliothèque Municipale, MS. I 84, fols. 78v-8I, 230-34v, 269v; MS. 193, fols. 88v, 89, 91, I 16-18; MS. 196, fols. 193v, I98v, 24I, 245; MS. 198, fols. 80 ff., 97-97v; Treasury of Auxerre Cathedral, MS. 6, fols. $48 \mathrm{v}$, IO $3 \mathrm{v}$ ff.; Bibliothèque Nationale, MS. lat. $943 \mathrm{I}$, fols. 98 , I 30, I32v; MS. lat. 9434, fol. 20Iv; Consuetudines ecclesiae beati Martini, 79. 
archbishop, I will analyze in greater detail the ritual of the July vigil and the stories about it. Again and again in their twelfth- and thirteenth-century accounts of the July visitations, the canons of the basilica eliminated all extraneous elements-spiritual edification, the welfare of souls-bringing their narratives around to a single message: the basilica possessed and was possessed by divine and episcopal power.

Philip and Renaud told several miracle stories to prove to Archbishop Philip of Cologne that Martin did indeed visit his church each year on the night of July 3. The first of those stories concerned a vision that the treasurer Herveus saw when he dedicated the basilica in IOI4. Herveus's experience had been recounted by two eleventhcentury authors-the Benedictine monk Ralph Glaber and an anonymous author who took the voice, in a dialogue, of Hugh, archdeacon of Saint-Martin. Both the differences between Hugh's and Ralph's accounts and the differences between the earlier and later versions of the event demonstrate the peculiar preoccupation of the canons of Saint-Martin and the evolution of their preoccupation between the early eleventh century and the late twelfth. ${ }^{7}$

According to Hugh's eleventh-century dialogue, the canons of Saint-Martin were bitterly disappointed in IOI 4 that Saint Martin did not bless the dedication of his new basilica with a miracle. The canons were looking for a material manifestation of divine presence in the form of a miraculous cure. But Herveus, who had been deeply influenced by Cluniac monasticism and who exceeded the piety of most monks with his private fasts and vigils, was better informed than his fellow canons. He learned that Martin did indeed bless the day of the dedication with a miracle but that it was a spiritual, rather than a material, miracle. 8

Rapt outside himself, Herveus saw Saint Martin standing before the "highest judge" and requesting that in honor of the dedication God release from otherworldly punishment three deceased canons of Martin's basilica. Those canons were "held in the places of punishment for the fault of heedlessness," but Martin argued that they "used to perform my remembrance with a special vow."9 God responded

7. "Hugonis Archidiaconi Turonensi dialogus," 213-17; Ralph Glaber, Historiarum libri quinque, 3:4, p. 64. For an earlier, and much briefer, comparison of the various versions of Herveus's vision, see Oury, "Idéal monastique dans la vie canoniale," I6-17. Oury was interested in monastic spirituality rather than the idea of focused power.

8. "Hugonis ... dialogus," 214-15. On Herveus's connections with Cluniac monasticism, see Oury, "Idéal monastique dans la vie canoniale."

9. "Conspectum summi Judicis," "tres officiales Fratres pro culpa temeritatis locis poenalibus tenentur constricti, qui tamen quoad vivebant, mei memoriam speciali voto agere consueverant" ("Hugonis ... dialogus," 215-16). 
that because Martin cared more about the redemption of souls than the health of bodies, he would bring out of hell-ab inferis - not only the three for whom Martin had intervened, but also as many souls as there were people in attendance at the dedication of the new basilica. Hugh equated this miracle with the work of the Redeemer himself, implying that Martin performed a second harrowing- "a new plundering"-of hell. 10

Hugh's story, with its stress on the possibility of release from otherworldly punishment, comes very close to the spiritual concerns of eleventh-century Benedictine monks. And indeed, it probably reflects how much Herveus's own spirituality temporarily affected the religious life at Saint-Martin. 11 Yet comparing this dialogue with Ralph Glaber's version of the story reveals significant differences between the concerns of black monks and those of the canons of SaintMartin.

In Ralph Glaber's story, it was Herveus who asked for a miraculous sign on the day of the dedication. In answer to this request, Saint Martin visited Herveus and told him the miracles of former days would have to suffice because the gathering of the harvest was near at hand. Martin informed Herveus that everyone should pray for only one kind of cure, the "raising of souls," and said he himself had interceded especially for the canons of Saint-Martin, "who assiduously serve God in this church." 12 The spiritual message of Ralph's story thus resembled that of Hugh's, except that Ralph made no direct connection between Martin's intercession and the dedication of the basilica. Unlike Hugh-or whoever wrote with Hugh's voiceRalph did not write as a propagandist for a sanctuary. He was not interested in Hugh's theme that Martin's power was focused at particular times and in one particular place-the basilica.

In one of the two letters they wrote to Archbishop Philip of Cologne in I I 80-8I, Philip and Renaud of Saint-Martin retold Ralph Glaber's version of the Herveus story, but they completely eliminated his monastic concern for the welfare of souls. Their preoccupation,

I0. "Nova spoliatione" ("Hugonis . . dialogus," 215-16).

I I. Another text reflecting a concern for souls at Saint-Martin at the time Herveus was treasurer is an anonymous life of Saint Martin: Vita Sancti Martini di anonimo. Two references praising Herveus and his new church suggest this was written soon af ter the dedication, and several passages emphasize the Last Judgment and the need for intervention and repentance: SI, 53, 4, S. For further discussion of this life, see my dissertation: "Societal Change and Religious Expression: Saint Martin's Cult at Tours, I050-1 200," 293-96.

12. "Tempori huic sufficere debent exibita dudum miracula, quoniam contiguum instat prius exsparsi seminis collecture messis. Sola enim animarum erigens medela exoranda est universis. . . Nam et pro his noveris me apud Dominum precipue intervenire qui illi assidue in presenti serviunt ecclesia" (Ralph Glaber, Historiarum libri, 3:4, p. 64). 
even more than in Hugh's dialogue, was to prove that Martin's power was focused in the basilica on the night of July 3. Herveus's story, Philip and Renaud proclaimed, was one of the "manifest signs and visions" proving that Martin did indeed visit his basilica during the vigil of his July feast. ${ }^{13}$

But Philip and Renaud knew an even better story, concerning an event that had taken place "most recently" and was still part of living memory. The canon Hildebert Paganus, who had accidentally witnessed the nocturnal visitation, described what he saw to a young canon who, in his old age, recounted the story to several canons who were still alive. ${ }^{14}$ On the night he saw the visiting saint, Hildebert was among those canons who were assigned to keep watch at the various doors of the basilica. But he could not sleep because he had left his pillow in the locked sanctuary, and so he decided to enter the basilica in the middle of the night and retrieve the pillow. Hildebert had no problem entering the church, but as he turned to leave, he found that his route was blocked "by a long procession coming out of the choir and circling around to the altar and sepulcher [of Saint Martin]." That procession, "worthy of reverence" was made up "of archbishops and bishops shining beyond all estimation with the adornment of wondrous beauty." 15

In recounting Hildebert's experience, Philip and Renaud stressed one thing: the awesome nature of supernatural presence. Hildebert had violated a fundamental taboo, and for that reason he was severely chastised:

While [Hildebert] stood with his eyes fixed on the unaccustomed brightness, confused in mind and frozen in body, he was seized by someone who had diverged a little in his direction from the splendid procession. That one bitterly chastised him because with rash temerity he had presumed to intrude upon the sanctuary on the very night that . . . Martin, the lord and possessor of the place . . . visits his temple, along with his companions-citizens of the celestial fatherland. 16

I3. "Signis et visionibus manif estis" ("De cultu Sancti Martini," 228). On the dates of Philip and Renaud's two letters, see Delehaye, "Guibert, Abbé de Florennes et de Gembloux," 48-65. This letter was written during Peter of Pavia's sojourn in Tours in April-May I I 8 I. The other letter was apparently written during Guibert's visit, which lasted from September I I 80 to May I I8I.

14. "Nuperrimis . . . diebus" ("De cultu Sancti Martini," 228, 230).

I 5. "Intermeantibus ad altare et sepulchrum pretiosi antistitis longae processionis ex chorea altari et sepulchro circumducta exeuntis, reverendo archipraesulum et episcoporum comitatu ultra omnem aestimationem mirae pulchritudinis ornatu fulgentium" ("De cultu Sancti Martini," 229).

16. "Qui dum oculis ad fulgorem insolitum mente consternatus et obrigescens corpore staret, ab uno ex illa processione praeclara ad ipsum paululum digrediente asperae invec- 
Hildebert's critic went on to tell him that he had been allowed to witness the procession not because he deserved such a favor but because he would tell others what he had seen. When Hildebert found the courage to ask who was participating in the procession, his interlocutor replied that he himself was "Martin, the lord of that palace" and that the other participants included those who had succeeded him as bishop of Tours, the bishops of other cities, and Euvert of Orléans, who "though hardly known to the world, nevertheless has great merits with God." After warning Hildebert "with severe threats" that he should never again enter the basilica on the night of the July vigil, Martin returned to his saintly companions, and Hildebert found himself transported, "as if by the hair," into the chapter room. 17

Philip and Renaud's claim that Martin returned to his church on the day of his feast was not unique-other saints did so too, at least on occasion. 18 But the liturgical practice of emptying and locking the church, which called attention to the saint's yearly presence, was at least unusual enough to arouse the curiosity of Archbishop Philip. 19 The miracle recounted by the canons resembled not only the accounts of saintly visitations, but also a more folkloric theme, which Alexander Krappe designated the "perilous chapel" or "the mass of the dead." 20 These stories about supernatural nocturnal church services stressed the breaking of a taboo-the violation of the boundary separating the living from the dead. Martin's reproaches to Hildebert were mild compared with the folkloric accounts, in which the intruders sometimes died. Yet the effect of Philip and Renaud's legend was similar to the folkloric stories. It provided no spiritual or moral edi-

tionis increpatione correptus est, quod ausu temerario praesumpsisset sanctuarium irrumpere, ea praesertim nocte qua . . . dominum et possessorem loci Martinum . . . cum consortibus suis, coelestis patriae civibus, visitare templum suum" ("De cultu Sancti Martini," 229).

17. "Martinum illius aulae dominum," "quamvis mundo non valde cognitum, magni tamen meriti apud Deum," "Severaque interminatione," "quasi per capillos" ("De cultu Sancti Martini," 229).

I8. Gregory of Tours told a story describing how Saint Martin went to Tours to celebrate his feast (this was cited by Philip and Renaud as further evidence of the July visitations); Saint Febronia was seen every year on the night of her feast praying in the place where she had formerly sung psalms; and Saint Benedict revealed that he was present at Saint-Benôit-sur-Loire for his feast of July 9: see Liber in gloria confessorum, 94, pp. 358-59; "De cultu Sancti Martini," 228; Thomais, Vita et martyrium S. Febroniae, 33; Miracles de Saint Benôit, I:40, pp. 83-86.

19. The door of Saint Foi's church at Conques was closed on the vigil of her feast because the clerics did not want the local devotees to disturb the office: see Bernard of Angers, Liber miraculorum Sancte Fidis, 2:12, pp. 120-21.

20. Krappe, "Squire's Adventure in Perlesvaus." Examples include Gregory of Tours, Liber in gloria confessorum, 72, pp. 340-4I; Thietmar of Merseberg, Chronicon I:7, p. 738. See also Thompson, Motif-Index of Folk Literature, vol. 2, no. E492. 
fication, since the only personal lesson one could deduce from it was to avoid entering Saint-Martin's church on the night of July 3. The story focused instead on eliciting fearful respect for supernatural presence. Its purpose was to demonstrate that Martin was indeed the spiritual possessor of the place that housed his relics, that his power was focused both in place and in time.21

The distinctive focus of the canons' various accounts of the July visitation can be highlighted, once again, by comparing their stories with a monastic version, recounted by a twelfth-century Cluniac named Walter in a small, and very early, collection of miracles of the Virgin. In some ways Walter's Martin resembled the Virgin-he was kind, gentle, and willing to bend the rules, and he offered hope for the spiritual welfare of the canon who witnessed the saintly visitation.

Walter's Martin differed from Philip and Renaud's Martin, and indeed, so did his canon. He was old, pious, and ready to die:

This one about whom we speak had been a righteous canon since his boyhood, leading an honest life without complaint in the same church. And when he was already truly decrepit, he distributed everything whatever that he was able to own to the church of the blessed Martin. And as we indicated above, since he now had nothing and felt his death to be near, he remained in the church on the night of the vigil of the translation of Saint Martin, after the people and the clergy had withdrawn. 22

Unlike Philip and Renaud, Walter implied that the merits of this canon earned him the right to witness the procession. The guardians of the church responded favorably when he requested permission to stay in the church. Similarly, when one of Saint Martin's entourage

21. One thirteenth-century story about the July vigil, by a canon of Saint-Martin, reiterated the same message: Péan Gatineau, Vie monseignor Saint Martin de Tors, lines 93939464, pp. I 18-19. For my argument that Péan's Life was written after I229, see Source Appendix, II-C.

22. "Hic autem, de quo loquimur canonicus a pueritia iustus in eadem ecclesia honestam et sine querela vitam duxerat, cum vero jam decrepitae esset aetatis omnia quaecunque habere potuit in ecclesia beati Martini distribuit, et cum iam nil penitus haberet, mortemque sibi sentiret adesse praesentem, ut jam praemisimus, vigilia translationis beati Martini, populo cum clero recedente, in supradicta remansit ecclesia" (Walter of Cluny, "De miraculis beatae Virginis Mariae," 654). This edition (by Labbe) of Walter's collection is in PL 173:1379-86, but the Martin miracle is not included. There is a variant of the text in the Catalogus codicum hagiographicorum . . parisiensi, I:I9-2I, but I will refer only to the Labbe text. The Histoire littéraire de la France, 12:49I-92, attributed this collection to Walter of Compiègne, a monk from Marmoutier, but as Halphen and Poupardin pointed out (Chroniques des comtes d'Anjou, xlii), the author identified himself(Labbe, 650) as "Gualterius Cluniacensis monachus," which suggests he was some other monk. 
pointed out to the saint that a living cleric was in the basilica, Martin replied, "Let... him stay, for he has come here with good intentions." 23

But when Saint Nicholas entered the basilica, red bearded and accompanied by a retinue of one hundred bishops, he insisted that the canon not remain, "because he has not yet obtained our fellowship from the Lord." 24 Thus prodded, Martin gently escorted the canon to the locked door of the basilica, opened it without a key, and suggested that he remain just outside the door to listen to the divine service. As he departed, the canon tearfully asked Martin to seek pardon for his sins, and Martin responded by predicting his imminent death and assuring him that he could take hope in Christ's clemency. He also told the canon that Saint Euvert, who was among the saints present that evening, had so much merit before God "that as long as the present world lasts, God frees, each day, one soul from the place of punishment because of his grace." 25 Philip and Renaud had made no connection between Euvert's merits and the easing of the punishment of sinners.

Like Philip and Renaud, Walter emphasized that Martin was present at his basilica on his feast day, and he depicted a boundary separating the realm of the living from that of the dead. Walter's boundary, however, was more permeable: Martin, at least, was willing to bend the rules and to pay heed to the canon's good intentions. And unlike Philip and Renaud, Walter was less interested in the theme of divine presence than in the salvation of souls and the possibility that interactions between the living and the dead could incur spiritual benefit for those who still needed help in cleansing themselves of their sins.

The ritual of the July vigil and the miracle stories the canons told about it spread the message that divine power dwelt at Saint-Martin's basilica. In itself this message was not unusual. Saints were supposed to perform miracles wherever their relics resided, thus demonstrating both their own holiness and the power of God. But the July miracles, or visitations, focused in a peculiar way on the issue of divine presence. They involved neither physical healing nor the welf are of souls.

23. "Permittite ... eum ibi manere, quia bona intentione huc advenit" (Walter of Cluny, "De miraculis beatae Virginis," 654).

24. "Quia necdum nostram societatem impetravit a Domino" (Walter of Cluny, "De miraculis beatae Virginis," 654).

25. "Ut quandiu praesens seculum duraverit, omni die animam unam a loco poenarum Dominus ob illius gratiam liberat" (Walter of Cluny, "De miraculis beatae Virginis," 654). 
On first consideration it might appear that the theatrical display of the July vigil was meant to impress pilgrims. Summer, after all, was the great season for pilgrimage, and the July feast might have caught some of the stragglers making their way to Compostella (Saint James's feast was on July 24). If indeed the stories about the July vigil were meant to impress pilgrims, the reason may have been that the rest of the world had forgotten Martin's July feast. The Guide of the Pilgrim of Compostella mentioned only Martin's feast of November I I, and Philip and Renaud acknowledged that it was the autumn feast that was known to all the world. 26

It seems, however, that the July vigil and its legends were intended for a more local audience. The theme of divine presence would have been relevant to the canons in their relations both with their archbishop and with the burghers of Tours, because it indicated that the basilica possessed a very special kind of power. Indeed, Philip and Renaud's account contained one theme that could have displeased the archbishop of Tours: Martin, they claimed, visited the basilica in the company of every deceased pontiff of Tours. On the night of July 3 , then, the cumulative weight and power of the episcopal tradition of Tours resided not at the cathedral, but at the basilica. This messagethat episcopal power was concentrated at the basilica-was conveyed by other legends and rituals of Saint-Martin as well.

Saint Martin and the Theban Martyrs:

Appropriating the Cathedral's Cult

In its underlying theme, Philip and Renaud's account of the July vigil resembled another story they told in response to the letter of Archbishop Philip of Cologne, who had heard "that it is said that while he was still living, [Martin], the holy priest, prayed at the place where the Theban martyrs were martyred, and in so doing he elicited out of the earth's dry bosom . . . some of the blood of those martyrs, many years after their passion." 27

Philip and Renaud confirmed the rumors that had reached Archbishop Philip and provided him with a full written version of the

26. Guide du pèlerin de Saint-Jacques de Compostelle, chap. 8, p. 6I; "De cultu Sancti Martini," 227, 236-39. See above at note 6 concerning the greater importance of the July feast in the early Middle Ages.

27. "Quod dicitur sanctus sacerdos adhuc vivens sanguinem martyrum Thebaeorum post multos passionis eorum annos, cum in loco martyrii eorum oraret ex arido terrae sinu, quo receptus fuerat, elicuisse" (Catalogus . . Bruxellensis, I:240). 


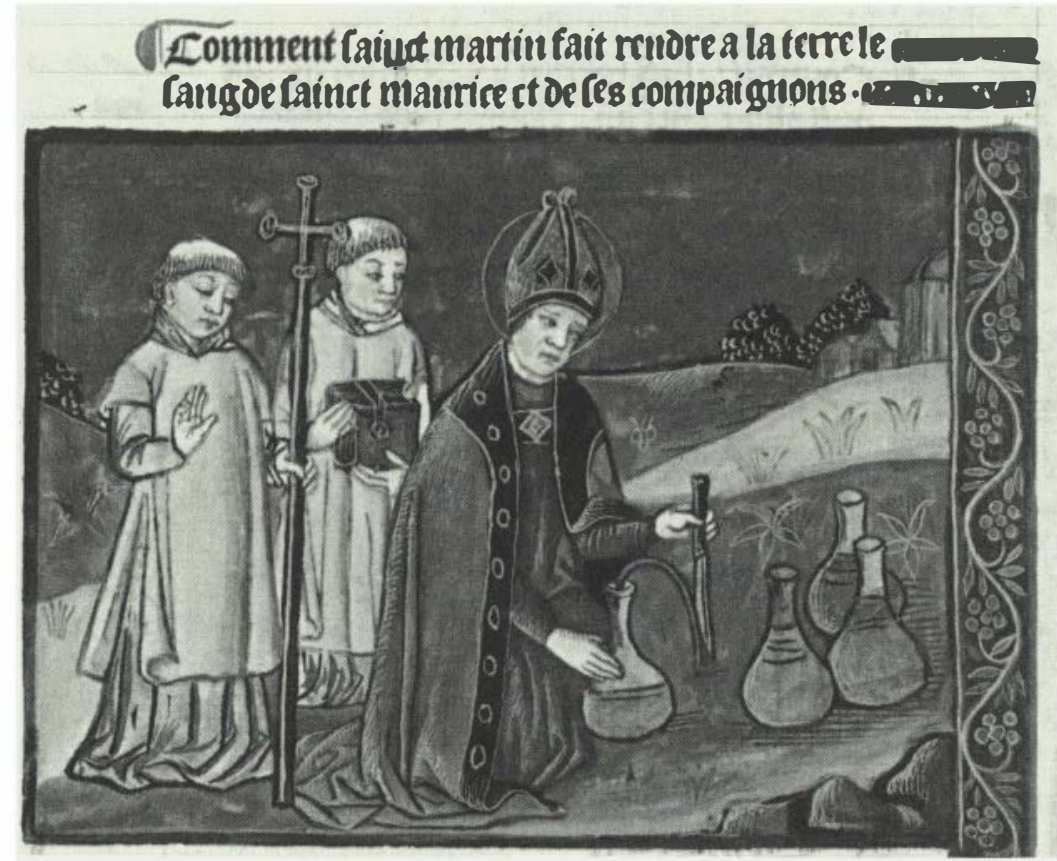

Plate 6. Saint Martin and the Theban relics. According to the late twelfth-century legend recounted by the dean and treasurer of Saint-Martin, Saint Martin went to the place where the Theban legion had been martyred and cut the earth with a knif e, causing a dense shower of blood to pour forth. This painted woodcut was one of several late medieval illustrations of the legend (Vie et les miracles de monseigneur Saint Martin, Diiii). Photograph courtesy Bibliothèque Nationale.

legend, which they associated with Martin's feast of May 12. While returning from a trip to Rome, they claimed, Martin decided to pray at the spot where Saint Maurice and his Theban legion had shed their blood. At the monastery of Agaune, now in Switzerland, he asked the monks for some of the Thebans' relics, but because they did not know Martin, the monks refused his request. Martin, however, learned from the local inhabitants precisely where the martyrs had died. After praying there, he cut the earth with a knife, releasing "a dense ... shower of abundant blood." Martin filled some vessels with the blood and started for home, but before he could leave God compelled him to return to the monastery "so that Martin, rejected, would appear as Martin, God's chosen pontiff" (see plate 6). Martin gave some of the martyrs' blood, along with the knife he had used to cut the turf, to the monks of Agaune; and upon returning to Tours he 
gave more blood to the cathedral of Tours and to that of Anjou, which he consecrated to Saint Maurice and his companions. 28

Philip and Renaud went on to explain that on May I2 they celebrated both this translation of Maurice's relics and Tours's deliverance from the Vikings (in 903). But their statements suggest that their legend concerning Martin's translation of the Thebans' blood was of recent origin. Martin, they claimed, was so devoted to the martyrs that he always carried an ampulla of their blood with him, and he even asked to be buried with it. "Only in our times" had that ampulla been discovered, in a hidden place near Martin's relics. "Almost all of us saw it brought forth, and we exhibited it for a long time, so that it could be revered and kissed by the people." 29 It was also in recent years that some canons from Agaune (there were no longer monks there) had come to Saint-Martin seeking alms after their church burned. At that time the canons of Saint-Martin asked the canons of Agaune to affirm the authenticity of their relics and of the legend about how Martin brought the blood to Tours from Agaune. 30

Liturgical manuscripts from Tours indicate that in the eleventh century the monks of Marmoutier already honored Saint Maurice on May I2.31 But there is no way to be sure that the eleventh-century liturgical calendars referred to this legend. And indeed, the probable date for the origin of the legend is the time of the "discovery" of the relics, which had taken place in the living memory of Philip and Renaud, who were writing in $\mathrm{I} 180-8 \mathrm{I}$.

It is most likely, therefore, that this legend, which represents a significant infringement by Martin's cult on the cult of the cathedral of Tours originated in the second half of the twelfth century. Since the

28. "Locum roseo quondam cruore purpuratum," "Dominatorem vitae et mortis oravit . . . densus . . c copiosi sanguinis imber," "ut Martinus abjectus, Martinus electus Dei pontifex appareret" (Traditio Turonensium de sanguine sanctorum Thebaeorum, 384-85). This text of the legend was excerpted by the Bollandists from one of the letters that Philip and Renaud wrote in II 80-8I, and indeed, the only way to read the complete legend in this edition is to intersperse the text in the Acta sanctorum with the corrections and additions in the edited text of the letters: see "De cultu Sancti Martini," 223. The legend is now edited integrally in Guibert, Abbot of Gembloux, Guiberti Gemblacensis epistolae, 73-75. I have followed one slight variation from the old edition ("dominatorem vitae" rather than "dominatorem terrae" in the newer edition, p. 73).

29. "Hanc nostris modo temporibus ex occulto secretario quod sub arca corporis ejus est, inventam . . prolatam omnes pene vidimus, populis salutandam et osculandam longo tempore exhibuimus" ("De cultu Sancti Martini," 223).

30. "De cultu Sancti Martini," 224. I can find no reference to this fire at the chapter of Agaune, which would provide a terminus ad quem for the discovery of the relics.

31. Tours, Bibliothèque Municipale, Missal from the Petit-Séminaire; Rouen, Bibliothèque Municipale, MS. 243. Both were from Marmoutier. See Bosseboeuf, "Missel de Marmoutier du XIe s."; Leroquais, Bréviaires manuscrits des bibliothèques publiques de France, 4:II5. 
sixth century, when Bishop Gregory of Tours found some relics of the Theban martyrs in the crypt of Saint-Martin's basilica and translated them to the cathedral, the cathedral had been dedicated to Saint Maurice. 32 The twelfth-century legend emphasized in a new way that the cathedral owed its relationship with its patron saint to the basilica, and to Saint Martin in particular. It asserted, moreover, that the basilica of Saint-Martin possessed a major portion of those relics. Like the story of Hildebert's vision during Martin's July feast, the story about the translation of the Theban relics suggested that some of the episcopal authority of Tours resided at the basilica. Martin, the patron saint of the basilica, first gave the cathedral the relics of its patron. But Martin had also reserved some of those relics for himself and his tomb, thus endowing the basilica with a portion of the cathedral's patronal relics.

\section{Visual Representations of Episcopal Authority}

Philip and Renaud's stories about the Theban relics and the July vigil drew particular attention to Saint Martin's attributes as priest and bishop. Martin was "God's chosen pontiff"; he appeared on July 3-the vigil of the feast that celebrated his ordination into the priesthood-with an entire retinue of bishops and archbishops; and during that visitation he performed the divine office. 33 This attention to Martin's sacerdotal and episcopal attributes appears as well in a missal from Saint-Martin (Tours, MS. 193) that was copied and illuminated about the time Philip and Renaud wrote their letters. 34

The offices for all four of Saint Martin's feasts are included in this missal, which was one of the basilica's most precious liturgical objects. The text for three of those four offices opens with a decorated letter depicting a scene from Martin's life. The illumination for the

32. Gregory of Tours, Historia Franconum, 10:3 I, pp. 534-35.

33. The phrase "God's chosen pontiff" had apparently been used to describe Martin in an inscription that was known to Alcuin: see Alcuin, "Sermo de transitu S. Martini," PL I01:662.

34. Tours, Bibliothèque Municipale, MS. 193. For a description of the manuscript and its date, see Catalogue général des manuscrits des bibliothèques publiques de France, 37:I, pp. I3539. Collon, the editor of this volume, based his date of about I I 75-80 on the paleography of the manuscript and on the fact that the name of Saint Thomas (Becket) was a later addition, implying that the manuscript was copied before Thomas's feast was widely celebrated. Garand, Grand, and Muzerelle basically agree with Collon, arguing that though the manuscript follows the calendar of Saint-Martin, the paleography suggests it was probably copied at Marmoutier during the abbacy of Herveus of Villepreux (I 177-87): Catalogue des manuscrits en écriture latine portant des indications de date, 7:535. 


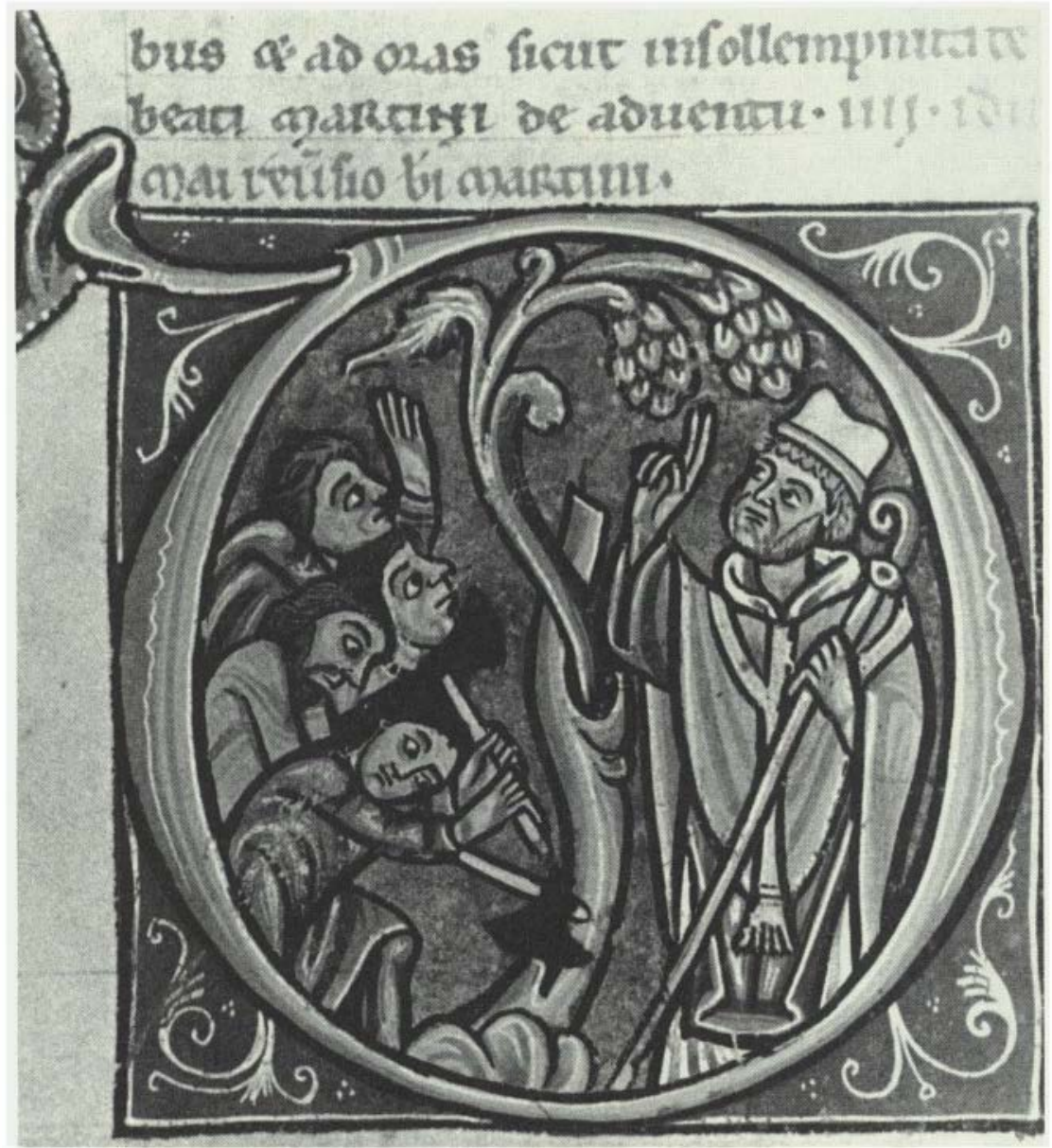

Plate 7. Saint Martin and the pagan tree. In this late twelfth-century illumination for Martin's feast of May I2, Martin wears full episcopal regalia, including the miter, even though he is outdoors, in a nonliturgical setting. As I note in chapter 9, the illumination does not depict the events that were actually celebrated on May I2-the routing of the Vikings by Martin's relics in 903. Rather, it depicts another of Martin's victories over pagans, taken from his Life: according to Sulpicius Severus, Martin proved the truth of the Christian faith by standing under a tree while pagans who worshiped the tree cut it down. The tree fell away from Martin, and the pagans converted to Christianity. Tours, Bibliothèque Municipale, MS. 193, fol. 78v. Photograph courtesy Tours, Bibliothèque Municipale. 


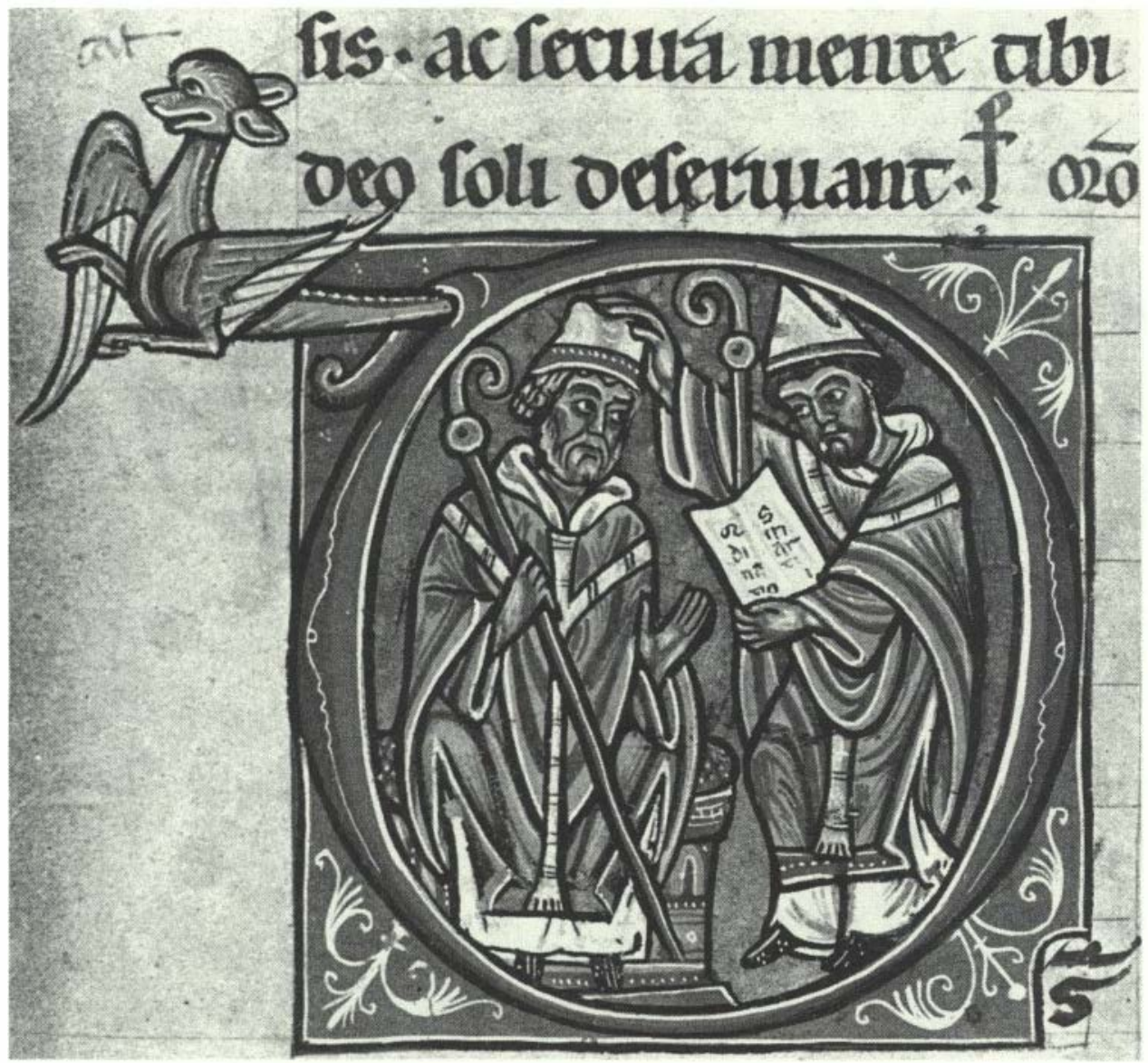

Plate 8. Saint Martin's ordination as bishop. In this illumination for Martin's feast of July 4 it is Martin, rather than the bishop who ordains him, who has a gray beard and gray hair. Tours, Bibliothèque Municipale, MS. 193, fol. 89 (late twelf th century). Photograph courtesy Institut de Recherche et d'Histoire des Textes, Centre Augustin Thierry, Orléans.

May feast (fol. 78v; plate 7), when Martin's relics saved Tours from invading pagan Vikings, depicts an earlier hostile encounter between the saint and pagans, when Martin proved the superiority of his God by standing under a sacred pine tree as the pagans cut it down. The illumination for the July feast (fol. 89; plate 8) depicts Martin's ordination as bishop; and that for the November feast (fol. I I 7; see plate I above)-the date of the saint's death-depicts not the pious moment when Martin died, but the nocturnal translation of his relics when the men of Tours passed his body out a window in Candes, 


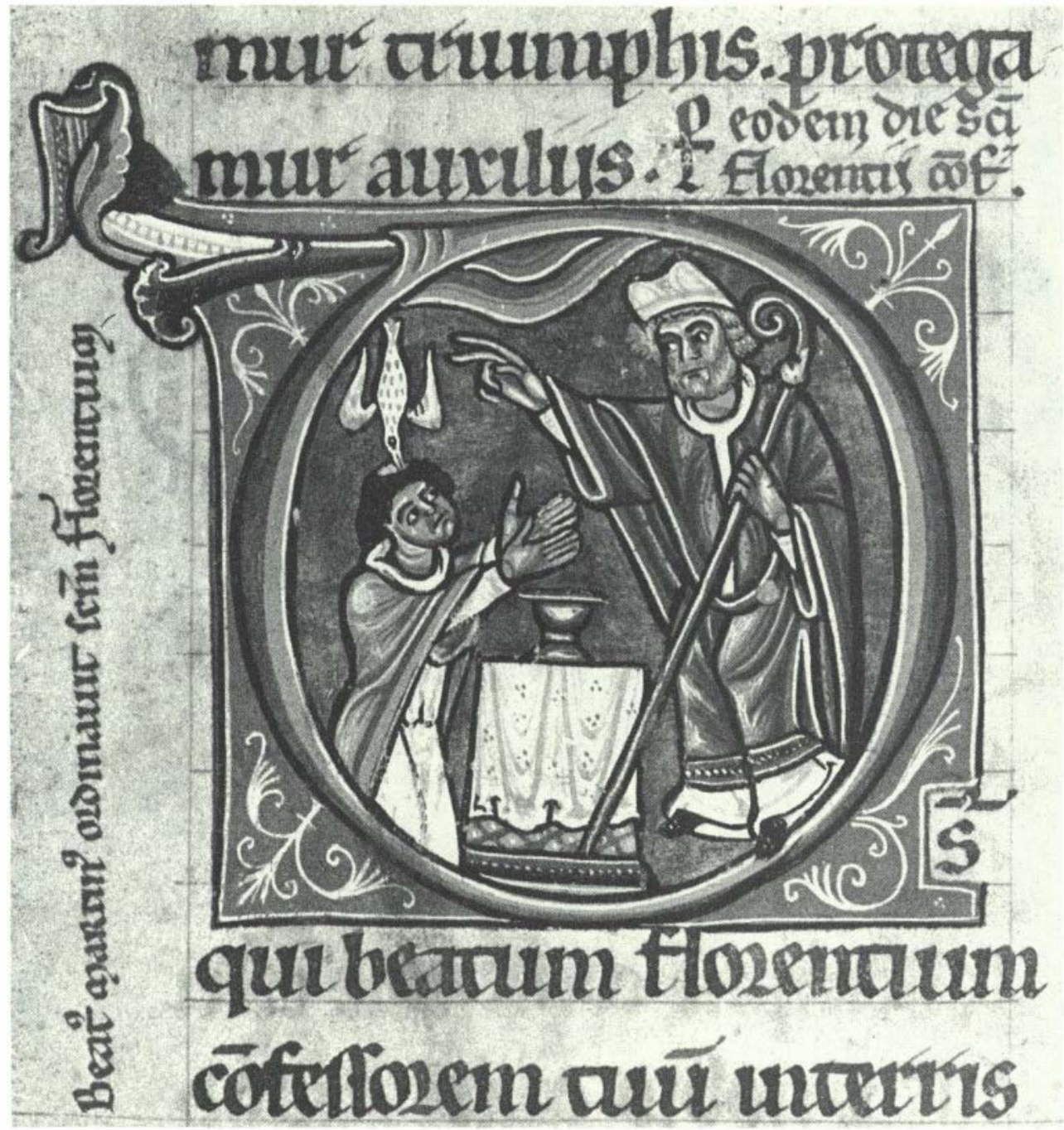

Plate 9. Saint Martin's apostolic dignity. Left: The dove of the Holy Spirit descends on Saint Florent when Saint Martin ordains him: illumination for the feast of Saint Florent, Tours, Bibliothèque Municipale, MS. 193, fol. I09. Right: The dove of the Holy Spirit descends on the apostles: illumination for the feast of Pentecost, Tours, Bibliothèque Municipale, MS. 193, fol. s6v. Like Saint Peter in the illumination on the right, Martin has gray hair and a gray beard; like the apostles, Martin is associated with the dove of the Holy Spirit. Photographs courtesy Institut de Recherche et d'Histoire des Textes, Centre Augustin Thierry, Orléans. 


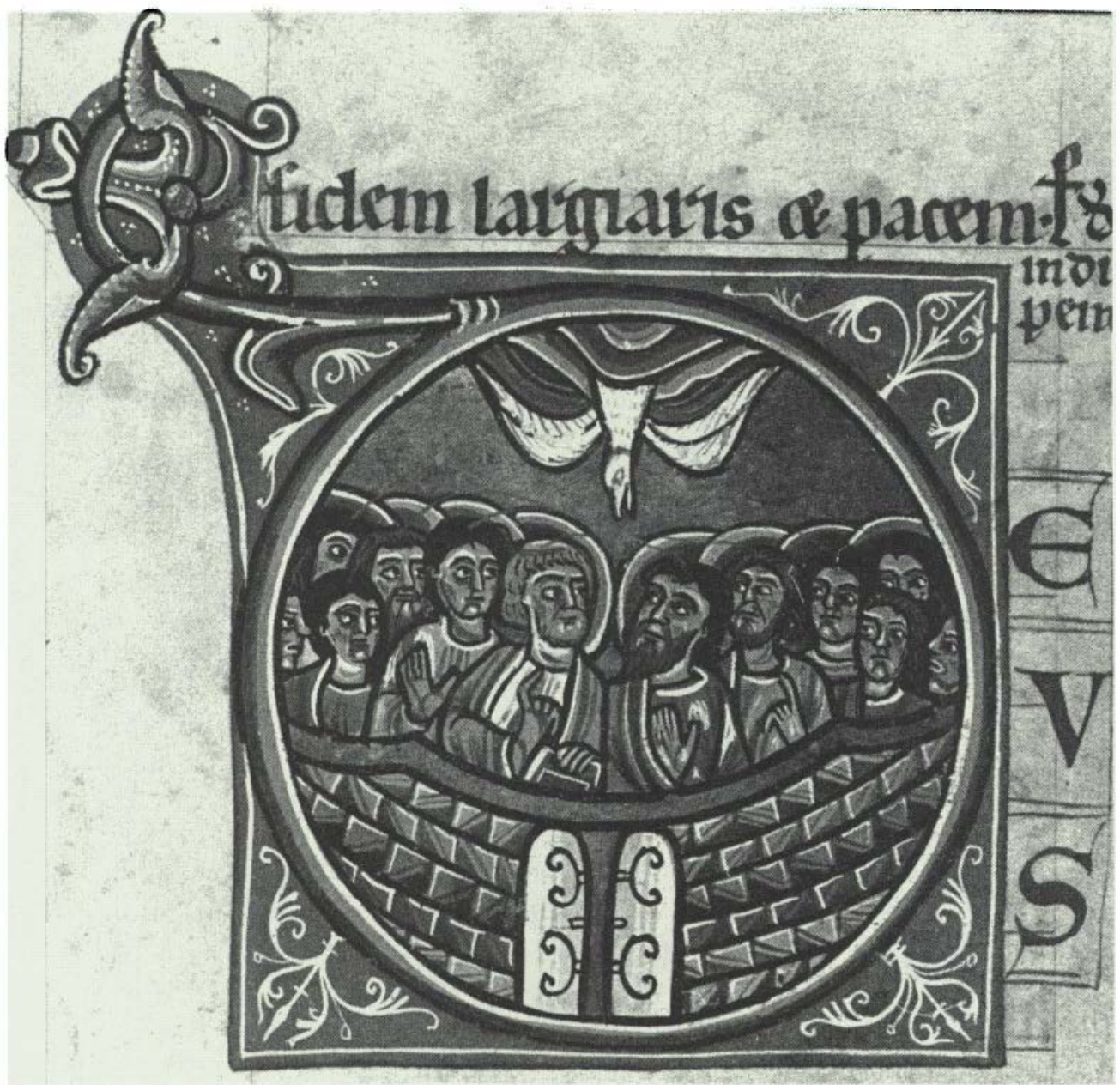

thus stealing it away from the men of Poitiers. Additionally, a fourth illuminated letter (fol. I09; plate 9), at the beginning of the office for the feast of Saint Florent, depicts Martin ordaining the other saint. As Martin extends his hand over Florent, the dove of the Holy Spirit descends upon the new priest. In all these illuminations Martin wears full liturgical vestments and a bishop's miter. In all but the one depicting the translation of his body, he carries a bishop's staff. And two of the illustrations focus on a moment of ordination: Martin's own and that of Saint Florent.

These four illuminated letters are the only ones in the manuscript 
that represent post-apostolic saints. With the exception of one letter depicting Saint Michael the Archangel and one for All Saints' Day, all the other illuminated letters concern scenes from the lives of Christ and of Mary and episodes in the history of the apostolic church. Additionally, two full-page and two half-page illuminations depict Christ on the cross, Christ in majesty, Christ extending a blessing, and personifications of the church and the synagogue. 35

Parallels between the illuminations of Martin and those of the apostles draw attention to Martin's dignity and apostolic nature. Martin, like Saint Peter in several other illuminations in the manuscript, has gray hair and a gray beard. ${ }^{36}$ This depiction of a patronal saint as an "elder" may have been a topos, but the parallel between Saint Martin and Saint Peter is striking. The uniqueness of the resemblance is highlighted, moreover, in that the bishop who ordains Martin has brown hair and a brown beard.

A second parallel linking Martin's miniatures to those of the apostles was the depiction of the dove of the Holy Spirit in the miniature for Florent's ordination. In a miniature for the feast of Pentecost (fol. s6v; plate 9) the dove also appeared, descending on all the apostles. The visual image for Florent's feast thus called attention to the concept of apostolic succession and to the idea that through the rite of ordination bishops preserved and transmitted the church's inheritance from the apostles. 37

In contrast to the eleventh-century illuminations in another manuscript from Saint-Martin (Tours, MS. IOI 8), these late twelfth-century illuminations persistently focus on Martin's ecclesiastical dignity and liturgical functions. The persistent representation, in the twelfthcentury manuscript, of Martin in a bishop's miter reflects the fact that the use of the miter, which began to spread in the late eleventh century, had become widespread by the end of the twelfth. Furthermore, that Martin was depicted in the miter even in the outdoor encounter with the sacred pine calls attention to the liturgical emphasis of the illuminations: the miter was part of a bishop's liturgical costume. ${ }^{38}$

35. Tours, Bibliothèque Municipale, MS. 193, fols. $17,21 \mathrm{v}, 48 \mathrm{v}, 54,56 \mathrm{v}, 59,69 \mathrm{v}, 70$, 7I, 7I v, 86, 98, I IOv, i I 5. For descriptions, see Dorange, Catalogue descriptif et raisonné des manuscrits de la bibliothèque de Tours, 104-6.

36. Tours, Bibliothèque Municipale, MS. 193, fol. 86, for the feast of Saints Peter and Paul; fol. 54 for the feast of Christ's ascension; fol. $56 \mathrm{v}$ for Pentecost; and fol. 98 for the feast of the Assumption of the Virgin.

37. On Florent's ordination by Saint Martin, see "Acta S. Florentii dubiae fidei auctore anonymo seculo IX scripta," 429.

38. Dix, Shape of the Liturgy, 405-7. 
The visual and legendary focus on Martin's priestly and episcopal functions, as well as on the splendor that signified the dignity of his hierarchical position, was not unique to the canons of his basilica. The general influence of the Gregorian reform had highlighted the authority and sacramental power of the priesthood. And in the face of the challenge of lay religious movements, more and more clerical authors began to stress the laity's necessary dependence on and obedience to the priestly hierarchy. Some clerical authors went so far as to insist that precious ornaments and noble horses were necessary possessions for a person holding ecclesiastical office, because such outward trappings instilled obedience in one's subjects. 39

These hierarchical concerns heightened clerical interest, not only in Tours but in other religious centers as well, in Saint Martin's episcopal and priestly attributes and in the dignity of his position. Toward the middle of the thirteenth century, Jacob of Voragine echoed the new concerns when he described Saint Martin in the Golden Legend. Voragine's descriptions of the saint diverged significantly from those of Sulpicius Severus's fourth-century Life of Saint Martin.

Sulpicius had emphasized that despite his accession to episcopal office Martin maintained his monastic virtues, "the same humility in his heart, the same poverty in his dress." For Sulpicius the monastic state was superior to the episcopal, and indeed, as bishop Martin did not have "that fullness of miraculous power" that he had as a monk. After he became bishop, Sulpicius pointed out, Martin resuscitated only one dead man; before he became bishop, he had resuscitated two. 40 In contrast to Sulpicius, Jacob of Voragine depicted Martin's accession to episcopal office as an increase in dignity over his monastic state, and he did not mention Martin's continued observance of monastic poverty and humility once he became bishop. Also, because the episcopate represented the superior state, Jacob transferred all Martin's resuscitations to that period in his life. 41

The most blatant example of Martin's new function as exemplar of priestly and episcopal dignity is the theme of the "mass of Saint

39. See chapter 7 , note I4.

40. Sulpicius Severus, Vita Sancti Martini, 10, p. 272; Sulpicius Severus, Dialogi, 2:4, p. I 84. Translations by Peebles, I I 7, 206.

4I. Reames, "Saint Martin of Tours in the Legenda Aurea and Before"; and Reames, Legenda Aurea: A Reexamination of Its Paradoxical History, 107-1 3. See also Alain Boureau's discussion of Voragine's classification of saints into three hierarchical categories: witnesses (those, like monks, who are perfect but not active); defenders (bishops and confessors especially - those who protect the Christian community and fight the devil); and preachers ("Structures narratives de la Legenda aurea," $68 \mathrm{ff}$.). 
Martin," which the liturgist Johannis Beleth first fully articulated about I I60. Beleth developed this theme to explain why Saint Martin deserved the unique epithet "equal to the apostles." When Saint Odo of Cluny gave Martin that title in the tenth century, he explained that it was because Martin had resuscitated three dead men. Beleth argued that this explanation could not work, because the achievement of raising the dead was not unique to Martin. Rather, Beleth suggested, Martin deserved to be called "equal to the apostles" because he had his own Pentecost. Before he went to celebrate mass one day, Martin gave his tunic to a poor man and replaced it with a vile one that was too short and had sleeves that reached only to his elbows. Martin went on to perform the mass wearing this undignified garment under his vestments. As he began to recite the preface to the mass, he raised his arms and the loose sleeves of his vestments fell back, exposing his bare arms. At that moment, however, "gold rings miraculously came forth and decently covered his arms, and a globe of fire appeared above his head, through which it was demonstrated that, with respect to authority, the Holy Spirit descended on him just as it did on the apostles on the day of Pentecost." 42 In telling this story, Beleth distorted Sulpicius Severus's original account. Sulpicius made no mention of the length of the garment and the problem of the bare arms; nor did he connect the globe of fire over Martin's head with the Holy Spirit and Pentecost. Rather, his main concern was the charitable indifference with which Martin approached the dignity of his priestly office. 43

Beleth singled out this event and molded it so that it fit a genre of priestly eucharistic miracles that had been gaining prominence in the

42. "Miraculose proueniunt aurei torques ipsaque decenter operiunt, et globus igneus apparuit super caput eius, per quod demonstratum est Spiritum Sanctum super eum descendisse ad robur, sicut super apostolos in Pentecoste" (Johannis Beleth, Summa de ecclesiasticis officiis, chap. 163, ed. Douteil, 2:320-21). Odo of Cluny first called Martin "par apostolis" in his hymn "De S. Martino Turonorum archiepiscopo," PL I 33:SI s. Sulpicius Severus associated Martin with the terms "apostle" and "apostolic" without calling him "equal to the apostles"; Fortunatus had called Martin "conpar apostolis": Sulpicius Severus, Vita Sancti Martini, 7:7, 20: I, pp. 268, 294; Sulpicius Severus, Epistolae, I:5, 2:8, pp. 31 8 , 328; Sulpicius Severus, Chronica, 2:50:4, p. I03; Sulpicius Severus, Dialogi, 2:5:2, p. I83; Fortunatus, Vita Sancti Martini, 2:46o, p. 329. On the phrase "par apostolis," see Du Cange, Glossarium, 6:147.

43. Sulpicius Severus, Dialogi, 2:I-2, pp. I 80-82. Sulpicius describes only flames over Martin's head. In describing the gold rings that covered Martin's arms, Beleth borrowed from and transformed another passage in Sulpicius's dialogues, in which a certain Arborius claimed that "once, when Martin was offering the sacrifice, he saw the saint's hands, decked as it were with precious jewels," Dialogi, 3:10, p. 208; trans. Peebles, 238. Again, Sulpicius made no mention of bare arms. 
twelfth century. ${ }^{44}$ His theme also supported an idea that clerics were emphasizing in the face of popular religious movements and heresies: that apostolic grace belonged exclusively to the priesthood and was passed on from one generation to another by the bishops. "The bishop," Hugh of Rouen declared, "is the foundation of the church, because through the bishop the church has the Holy Spirit." 45

Probably for these reasons, Beleth's account of the "mass of Saint Martin" was incorporated into the Golden Legend, William Durand's treatise on the divine office, and a number of widely disseminated collections of sermons and exempla. 46 Beleth's story also became the basis for a number of iconographic representations of Saint Martin, and we find that in some depictions the miracle occurred not when Martin raised his arms for the preface, but when he raised the chalice or the host at the moment of consecration. The seal of Aubry Cornut, dean of Saint-Martin from I 229 to I 236, for instance, depicts Martin raising the chalice while flames-the flames of the Holy Spiritdescend upon his head (see plate I0). 47 The ritual moment of consecration, which highlighted the priest's power to bring Christ's flesh and blood into the world, was the subject of much theological discussion in the twelfth century. One preacher declared in a sermon addressed to priests that God had caused Christ's incarnation only once, through the Virgin's womb, but "you do it daily, at the altar." 48 The visual representations of the mass of Saint Martin reinforced this idea.

44. Dumoutet, Corpus Domini: Aux sources de la piété eucharistique médiévale, I I7-26; Browe, Eucharistischen Wunder des Mittelalters, esp. 16-20; and Bynum, Holy Feast and Holy Fast, SI.

45. "Est episcopus ecclesiae fundamentum, quia per episcopum habit ecclesia Spiritum Sanctum" (Hugh of Rouen, "Contra haereticos libri tres," 2:I, PL 192: 1275).

46. Jacob of Voragine, Legenda aurea, chap. I66,pp. 746-47 (mentions that Johannis Beleth added the part about the arms not being covered); William Durand, Rationale divinorum officiorum, 708-9 (very close to Beleth's text); Maurice of Sully, "Homilie pour la fête de St. Martin" (no mention of charity); Caesarius of Heisterbach, Dialogus miraculorum, 9:3 I, ed. Strange, 2:1 88-89 (no mention of charity); Alphabet of Tales, 323; Adam of Perseigne (a monk of Marmoutier, writing ca. I I 8o-8 I for Guibert of Gembloux), "Epistola ad S. Martini cultores," PL 2I I:668-72 (gives Beleth's arguments as well as those of Odo of Cluny and others); Péan Gatineau (a canon of Saint-Martin, writing ca. 1229), Vie monseignor Saint Martin de Tors, lines 421-56, I019-84, pp. 8, I5-16.

47. Archives Nationales, Service des Sceaux, D. 7599. On Aubrey's dates, see Griffiths, "Capetian Kings and St. Martin of Tours," I1 7. A fifteenth-century woodcut from Tours shows Martin raising the host while the angels cover his arms and flames descend on his head: see Vie et les miracles de monseigneur Saint Martin, ciiii.

48. "Hoc opus [Deus] fecit semel in uirgine, uos in altari cotidie" (Peter Comestor, "Sermo ad sacerdotes," 2 I3). On the twelf th-century emphasis on the sacramental power of the priesthood and the priest's ability to incarnate Christ, see Kennedy, "Moment of Consecration and Elevation of the Host," I 2 I-50; Dumoutet, Corpus Domini; and Bynum, Holy Feast and Holy Fast, 57. 


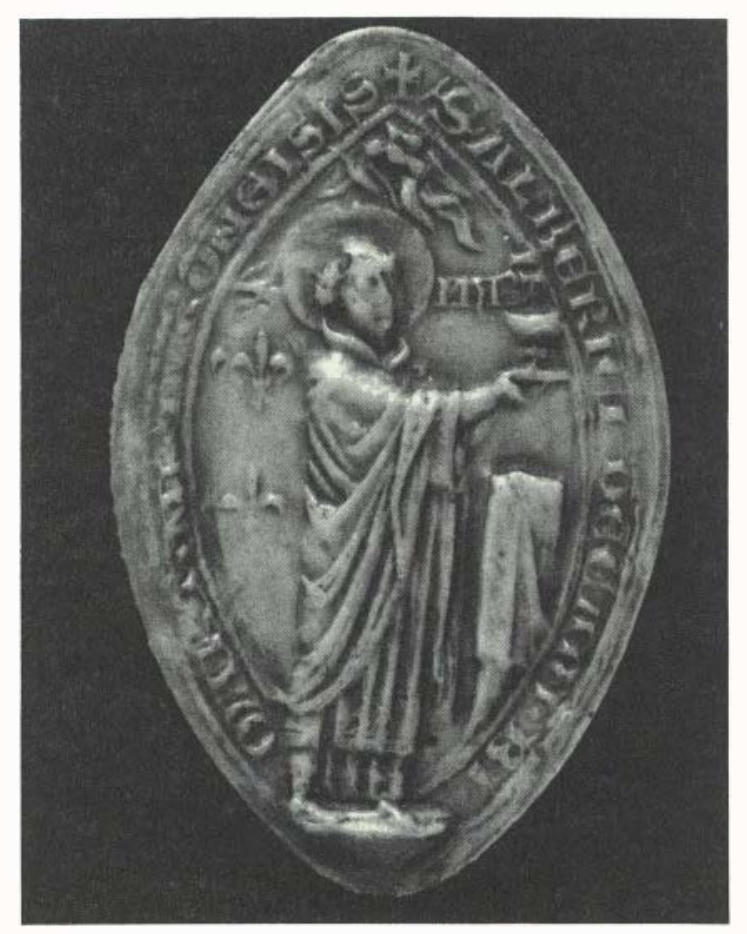

Plate r o. The mass of Saint Martin. The seal of Aubry Cornut, who was dean of SaintMartin between 1229 and 1236, depicts the flames of the Holy Spirit descending on Martin while he lifts the chalice during the mass. In Johannis Beleth's twelfth-century account of this event the flames-which made Martin "equal to the apostles"- descended on the saint as he lifted his arms during the preface to the mass. Beleth's story, and the visual elaborations of it, point to a high and late medieval interest in the apostolic grace that belonged exclusively to the priesthood. Paris, Archives Nationales, Service des Sceaux, D.7599. Photograph courtesy Archives Nationales.

Struggles over Episcopal Prerogatives:

Saint-Martin's Rituals of Dominance

The attention that the canons of Saint-Martin were paying, about the year II 8o, to Martin's priestly, sacramental, and episcopal attributes is thus representative of a general clerical interest in the power of the priesthood and the hierarchical authority of bishops. Nevertheless, this general context provides only a partial explanation for the visual and legendary products of the canons of Saint-Martin or for their ritual behavior. In the context of their own diocese, the canons were more interested in appropriating episcopal authority for them- 
selves than in supporting the hierarchical authority of their archbishop. Their interest in this appropriation had been accelerating since the late II sos, when the archbishop of Tours began a campaign to win back and expand his jurisdictional prerogatives within his diocese. ${ }^{49}$ In their confrontations with Saint-Martin, the archbishops' attention focused on the religious houses that were subordinated to the basilica. By the early thirteenth century, some of those subordinate houses took the initiative in trying to gain greater independence from the domination of the basilica.

Sometime after 1226, and before the struggles with the archbishop and the subordinate houses had all been resolved, one of the canons of Saint-Martin put into writing the liturgical customs of the basilica. Although the customal described a number of legal rights and rituals that had arisen at earlier dates, it seems that its author's central purpose was to bolster, and perhaps extend, the canons' symbolic power. The customal described a system of rituals that called attention to Saint-Martin's rights of lordship. Many of these rituals were formal expressions of jurisdiction over a religious community. Others, however, served the broader function of defining the basilica as the hub of an ecclesiastical community. Unlike Philip and Renaud's legends and the images in the twelfth-century missal, which suggested only that episcopal dignity resided at the basilica, the rituals in the customal demonstrated that episcopal dignity and authority emanated from the basilica.

The basilica's ritualized expressions of dominance focused primarily on five religious communities in and around Châteauneuf. Just outside the walls of Châteauneuf were the tiny secular chapters of Saint-Pierre-le-Puellier and Saint-Venant. To the southwest, about one kilometer away, stood Beaumont, a house of nuns founded in I007 by Saint-Martin's treasurer, Herveus. About three kilometers to the west stood Saint-Cosme, a priory of regular canons founded by canons from Saint-Martin in I092. And finally, about seventeen kilo-

49. The Chronicon Turonense auctore anonymo, written by a canon of Saint-Martin, singles out Joscius (I I 57-74), Geoffrey du Lude (1 206-8), and John de Faye (1 208-29) as the aggressive archbishops. It explicitly states that Bartholemy of Vendôme (II 74-I 206) was not an aggressor, but a struggle in I 176 over the election of the abbot of Cormery (see below at note 6I) suggests that he too was engaged in the more aggressive archiepiscopal politics: see Chronicon Turonense, 1020, 1042. The charters of Saint-Julian of Tours indicate that jurisdictional struggles between the cathedral and that abbey also accelerated at the time of Archbishop Joscius and continued into the second quarter of the thirteenth century: see Chartes de Saint-Julien de Tours, I:129-30, 2:9-10, 12-17. Martène claimed that the abbot who was elected at Saint-Julian in I I so refused to take an oath of obedience to the archbishop of Tours. I do not know Martène's source: see Histoire de l'abbaye de Marmoutier, I:553. 


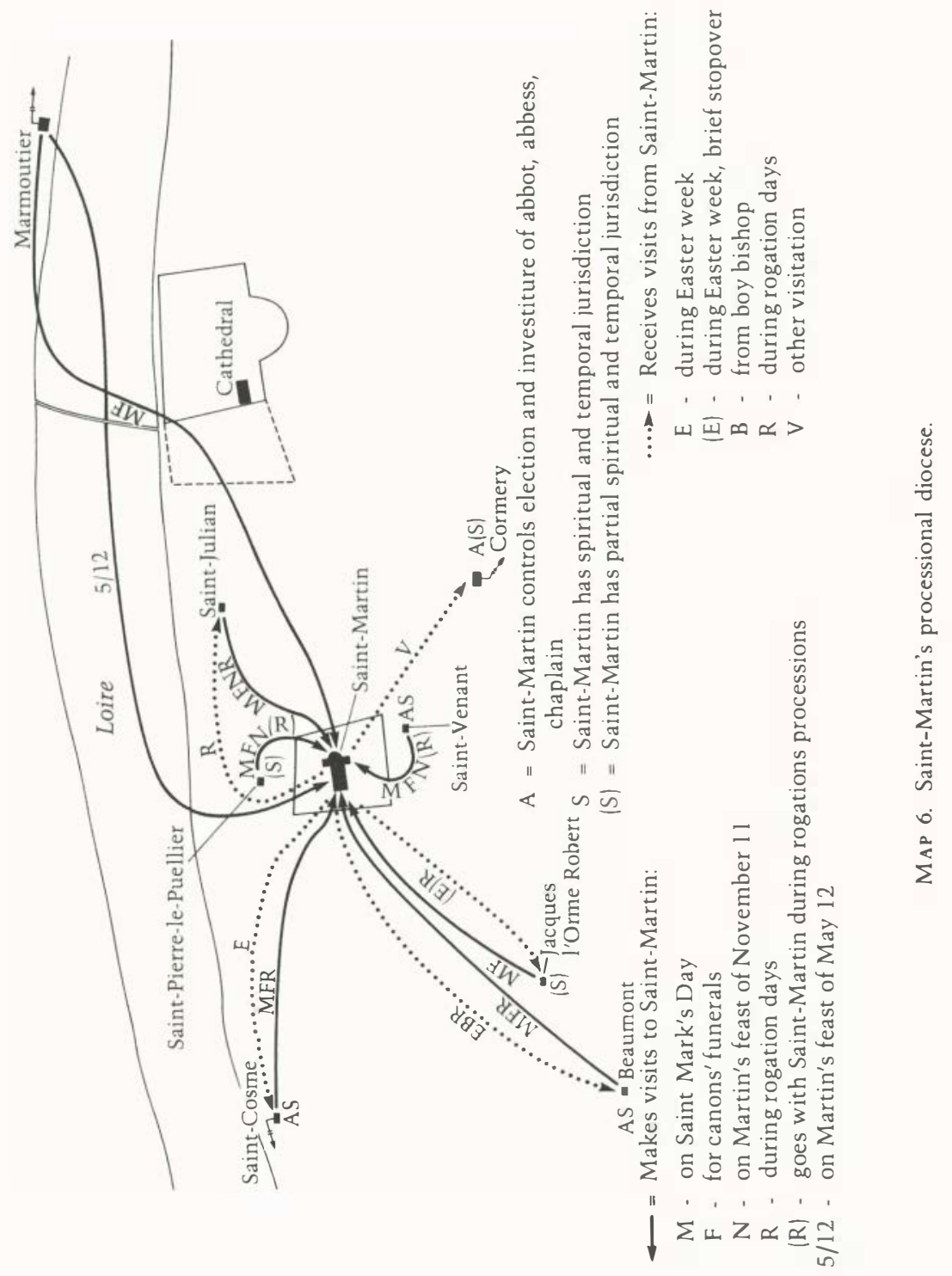


meters to the southeast there was Cormery, founded by Abbot Ithier of Saint-Martin in the ninth century and transformed into a Benedictine monastery by Ithier's successor, Alcuin of York (see map 6). 50 Between II 63 and the time when the customal was written, each of these five communities became the focus of struggles between SaintMartin and the archbishop of Tours. The communities of SaintVenant and Cormery also made a number of attempts to enhance their independence.

According to Saint-Martin's customal, the canons exercised some kind of jurisdiction over these five houses. The customal claimed "all spiritual and temporal jurisdiction" over three of the houses-SaintVenant, Saint-Cosme, and Beaumont. ${ }^{51}$ It is reasonable to assume, however, that before the mid-twelfth century, when the bishop began to win back some spiritual rights, the canons had claimed similar rights over Saint-Pierre-le-Puellier and Cormery.

By virtue of their partial and total jurisdiction over these five communities, the canons of Saint-Martin assumed the right to engage in certain rituals of domination that were denied to the archbishop in his relations with exempt houses, such as Saint-Martin and Marmoutier. First, according to the customal, the canons partially controlled the process of electing and investing spiritual leaders. Saint-Martin was involved in both the election and the investiture of every new prior, abbess, and abbot of Saint-Cosme, Beaumont, and Cormery. At Saint-Venant, which did not have an abbot or a prior, Saint-Martin was involved in the investiture of the community's chaplain. Only in the case of Saint-Pierre-le-Puellier were the canons of the basilica excluded from the process of electing and investing a spiritual leader. It is possible, however, that before II63, when Pope Alexander III intervened in favor of the archbishop's jurisdiction over Saint-Pierre, Saint-Martin's spiritual lordship over that house had been more extensive. 52

5o. On the foundation of Saint-Cosme, see the introduction to part 3 at note is; on the foundation of Beaumont, see Oury, "Idéal monastique dans la vie canoniale," 2 I; and Gallia Christiana, vol. I4, Instrumenta, 63-64; on Cormery, see Cartulaire de Cormery, v-xxiv, 38; Chélini, "Alcuin, Charlemagne, et Saint-Martin de Tours," 40.

5I. Consuetudines ecclesiae beati Martini, 140-4I.

52. Alexander III's summary of the arguments presented to him by the archbishop of Tours and the canons of Saint-Martin reported that the archbishop had always exercised the right of conf erring the holy oil and chrism to the priests of Saint-Pierre-le-Puellier (this was in contrast to Beaumont, where the canons of Saint-Martin conf erred these elements to the abbess). It seems, however, that the canons did claim the right of presentation: "De clericis uero beati Petri ad ordines promouendis testes hinc inde producti sunt, qui super hoc capitulo diuersa et uaria proponebant." Alexander decided that the archbishop would always confer the chrism and that only in some cases would the canons of Saint-Martin have 
The communities of Cormery, Saint-Cosme, and Beaumont had to seek permission before they could elect a new abbot, prior, or abbess; all three houses had to defer a disputed election to SaintMartin; and all three had to send their leader to the basilica to swear an oath of fidelity and obedience to Saint-Martin before being invested by the canons of the basilica with the cura animarum. After the canons of Saint-Martin invested a new spiritual leader, that candidate-like the abbot-elect of Marmoutier - still needed to be consecrated by a bishop. Unlike Saint-Martin's subordinate houses, however, Marmoutier gained the right in 1089 to go to any bishop for consecration if the archbishop of Tours did not wish to cooperate. 53

In the case of Cormery, spiritual investiture involved an elaborate ritual established by Urban II in I096. Whenever an abbot died his pastoral staff was given back to the canons of Saint-Martin, who placed it on the tomb of Saint Martin. After a new abbot of Cormery had sworn his oath of obedience, the canons took him to the tomb and invested him with the pastoral staff. 54

According to the thirteenth-century customal, the canons of SaintMartin could refuse to invest abbatial and prioral candidates from Cormery and Saint-Cosme. 55 This claim suggests that Saint-Martin had expanded its rights over Saint-Cosme since its foundation in I092: the foundation charter had stipulated that if the priory became large enough to constitute a regular community, its members could elect their own priors and present them to the chapter of SaintMartin, which could not refuse those candidates. 56

The chapter of Saint-Venant did not have a prior or dean, but the canons there did elect a chaplain who was invested at Saint-Martin with the cura animarum. Furthermore, Saint-Venant's dependence on Saint-Martin was such that the canons there were not allowed to have

the right of presentation: "De representatione autem clericorum Sancti Petri, qui ad ordines fuerint promouendi . . . clerici sancti Petri, qui canonici sancti Mart(ini) uel sancti Uenanti fuerint, a capitulo sancti Martini debeant archiepiscopo presentari; alii uero, qui clerici sancti Petri tantum existunt, a clericis eiusdem ecclesie archiepiscopo, cum ordinandi fuerint, presententur" (Letter of Alexander III to Archbishop Joscius of Tours [ 1163 ], in Papsturkunden in Frankreich, n.s. 5, no. 123, pp. 216-17).

53. Consuetudines ecclesiae beati Martini, I38-41; Bull of Urban II, in Papsturkunden in Frankreich, n.s. S, no. 21, p. 84.

54. Consuetudines ecclesiae beati Martini, I38; Gallia Christiana, vol. I4, Instrumenta, 74; Cartulaire de Cormery, 44, pp. 88-90. Urban II had to intervene in the relations between Saint-Martin and Cormery because the count of Anjou was attempting to extract the abbey from Saint-Martin's control: Guillot, Comte d'Anjou, r:167-73.

55. Consuetudines ecclesiae beati Martini, 138, 141 .

56. Vaucelle, Collégiale de Saint-Martin, 262; Foundation charter of Saint-Cosme, Tours, Bibliothèque Municipale, MS. I295, p. 605. 
their own seal, and they could not confirm any legal act without getting the canons of Saint-Martin to apply their seal to it. Concerning Saint-Pierre-le-Puellier, the customal indicated that Saint-Martin held all the same rights there that it held at Saint-Venant except that of parochial cura animarum. This suggests that Saint-Martin did not invest the chaplain of that house but that the canons of Saint-Pierre, like those of Saint-Venant, could not have their own seal.57

Certain rituals reinforced the blurring of the legal identities of Saint-Venant and Saint-Pierre with that of Saint-Martin. The two subordinate houses joined Saint-Martin in its processions but were not allowed to carry a cross, which would have symbolized their separate corporate identities. In the funeral procession for a canon of Saint-Martin, the canons of Saint-Venant and Saint-Pierre walked with the canons of Saint-Martin rather than separately, as did the monks of Marmoutier and Saint-Julian, the nuns of Beaumont, and the canons of Saint-Cosme. And during rogations, Saint-Martin did not visit Saint-Venant and Saint-Pierre. Rather, the canons of those two houses accompanied the canons of Saint-Martin in a procession to Saint-Julian. 58

Saint-Martin's jurisdiction over elections and investitures at SaintCosme, Beaumont, Cormery, and Saint-Venant represented one aspect of its spiritual lordship, which rivaled the archbishop's within the confines of his own diocese. Indeed, it is not surprising that many of the jurisdictional struggles between the archbishop and Saint-Martin concerned either the process of making a new spiritual leader or the lordship that control over that process symbolized.

On three occasions in the second half of the twelfth century SaintMartin's rights over the abbot of Cormery became the focus of a struggle with the archbishop. Sometime between II 57 and II74, Archbishop Joscius demanded that the new abbot of Cormery take on oath of obedience, which the canons and the abbey protested.59 In I I74, however, two arbitrating bishops who had been appointed by the pope decided that new abbots of Cormery were indeed to make an oral promise of "obedience, subjection, and reverence" to the arch-

57. Consuetudines ecclesiae beati Martini, 140-4I.

58. Consuetudines ecclesiae beati Martini, 140-4I, 133, 67. It seems that the rogation procession went by Saint-Pierre but did not enter it. In ${ }_{1} 163$ the canons of Saint-Martin attempted to use some of these rituals as evidence of their jurisdiction over Saint-Pierre: see Letter of Alexander III to Archbishop Joscius, in Papsturkunden in Frankreich, n.s. 5, no. 123, pp. 2 I5-I6.

59. Cartulaire de Cormery, 63, p. I 24 (the editor mistakenly dates this I 147, but Joscius was not bishop until II 57); letters of Alexander III and Lucius III, in Papsturkunden in Frankreich, n.s. S, nos. 167, 183, pp. 260-61, 276. 
bishop and that the archbishop had the right to depose culpable abbots of Cormery. It was probably for this reason that Saint-Martin's customal did not claim all "spiritual and temporal rights" over the abbey. 60

In I 76 the archbishop addressed the way Cormery's abbot-elect was presented to him for consecration. Because the canons of SaintMartin, rather than the monks of Cormery, claimed the right to present the abbot, the archbishop refused to consecrate him. The canons insisted there were many precedents for their action; the archbishop argued that the previous abbot had been presented to him by the monks of Cormery. A papal legate ruled that for the sake of the community of Cormery the archbishop should go ahead with the consecration, but he did not indicate how this dispute should be resolved in the future. 61

In 12 I 3 Innocent III responded to a dispute between the archbishop of Tours and Saint-Martin involving spiritual rights over Beaumont. The archbishop claimed he held the spiritual rights because one abbess had given an oath of obedience, reverence, and submission when he blessed her. The canons of Saint-Martin, claiming spiritual jurisdiction for themselves, replied that the nuns sought permission from the canons whenever they needed to elect a new abbess; that the canons of Saint-Martin installed the newly elected abbess; that they received, "in French," her oath of obedience, subjection, and reverence; and that they gave the abbess her pastoral staff, as well as holy oil, chrism, and the fire that was blessed on Easter. Innocent III's response was not sufficiently precise to resolve the dispute. Finally, in I 238 two arbitrators decided that Beaumont was under Saint-Martin's jurisdiction. From then on the abbess was to be blessed by the archbishop without any inquest into her election or morals and without any oath of obedience. If he refused to cooperate, she could receive her blessing from another archbishop. In 1243 the pope approved this arrangement. 62

Jurisdictional struggles between the archbishop and Saint-Martin over Saint-Pierre-le-Puellier, Saint-Cosme, and Saint-Venant tended to concern spiritual jurisdiction over the parishes belonging to those

6o. Cartulaire de Cormery, 66, pp. 127-30.

61. Letter of Peter of Grisogonus, in Papsturkunden in Frankreich, n.s. 5, no. 162, pp. $254-55$.

62. Innocent III, "Regestorum sive epistolarum liber duodecimus," I5:229, PL 216:764-66; Cartulaire de l'archevêché de Tours, 1:71-72; Bibliothèque Nationale, Collection Baluze, MS. 76, fols. I 89-I 89v (1 238 arbitration); Vaucelle, Collégiale de Saint-Martin, 25960; Grandmaison, Chronique de l'abbaye de Beaumont-lez-Tours, I I-I7 (Grandmaison cites the sources, but his narrative is confusing). 
houses. Also, with regard to spiritual jurisdiction over its parishes rather than over the monastery itself, the archbishop was able to regain some territory at Beaumont. In I 63 Archbishop Joscius asserted his "authority" and "rights" over Saint-Pierre-le-Puellier. He gained approval of his claims from the pope, but when the archbishop went to Saint-Pierre to make good his claims, the canons of SaintMartin locked him out. Nevertheless, the customal of Saint-Martin suggests that the canons were not able to persist in their resistance. 63 Similarly, the canons could not resist the archbishop's assertion of parochial rights at Beaumont. In I 2 I the archbishop gained parochial rights over the parish belonging to that abbey. The settlement stipulated that the abbess, or one of her priests, was to present to the archbishop, or one of his officers, the curate of the parish, who would swear obedience to the archbishop and receive from him or his representative the chrism and holy oil. In I238, when Saint-Martin gained recognition of its full spiritual rights over the nuns of Beaumont, the archbishop's rights over Beaumont's parishes were reaffirmed.64 The canons of Saint-Martin were apparently more successful in retaining parochial rights at Saint-Cosme and Saint-Venant. In I2 I the archbishop conceded to them the rights over the parishes of those two houses. 65

The process of electing and investing new spiritual leaders, and the implications of that process, also constituted a focus of strife between Saint-Martin and the subordinate communities themselves. In I 2 I I, as a result of an internal struggle with his own monks, the abbot of Cormery was compelled to acknowledge in writing that all disputes in his abbey, as well as disputed abbatial elections, had to be deferred to Saint-Martin. In I 2 I 2 a panel of external ecclesiastical judges determined that the canons of Saint-Martin did not have the right to prevent the monks of the abbey from holding an election. In 12 I 7 the two communities were again engaged in a struggle, though it is not clear that it involved abbatial elections. The abbot of Cormery had failed to respond to the canons' request that he appear before them, so

63. Vaucelle, Collé giale de Saint-Martin, 254; Joscius, archbishop of Tours, two letters to King Louis VII (I I63), Recueil des historiens des Gaules, I6:49-50; Letter of Alexander III to Archbishop Joscius (II63), in Papsturkunden in Frankreich, n.s. 5, no. 123, pp. 214-17; Consuetudines ecclesiae beati Martini, I40-4I.

64. Cartulaire de l'archevêché de Tours, no. 35, I:73-75; Bibliothèque Nationale, Collection Baluze, MS. 76, fols. 213-I4 (I2 I I), fols. I 89-I 89v (1238); Grandmaison, Chronique de l'abbaye de Beaumont, I I-I2; Vaucelle, Collégiale de Saint-Martin, 259-60.

65. Vaucelle, Collégiale de Saint-Martin, 253; Tours, Bibliothèque Municipale, MS. 1294, p. So; Mabille, Pancarte noire de Saint-Martin, 148, p. 464. Chronicon Turonense auctore anonymo, 1042. 
the canons, as was their right, seized all the property of the monastery. 66 In 1214 the canons of Saint-Venant also failed to appear when summoned to Saint-Martin, which was demanding reprisals because Saint-Venant had attempted to carry out a legal action without the permission of the canons at the basilica. The canons of Saint-Venant were finally forced to submit when Saint-Martin placed them under interdict and withheld the benefice they normally received from the basilica. 67

In addition to controlling elections, investiture, and the right to take legal action, Saint-Martin exercised the right to be received in processions at several of the subordinate houses and to be given food, lodging, or both. These processions served to define geographical space and to remind the local community that Saint-Martin had jurisdiction over its subordinate houses.

Probably because it was too far from Tours, the abbey of Cormery did not play a regular role in Saint-Martin's annual processional calendar as we know it from the thirteenth-century customal. But that customal shows that the monks of Cormery were obliged to receive the dean of Saint-Martin with a procession the first time he visited there after his accession to office and whenever he returned from Rome. On those occasions, the monks owed procuration to the dean; that is, they were obliged to feed him and give him shelter. The dean's right to a procession at Cormery paralleled the archbishop of Tours's right to a procession at Saint-Martin on the day of his consecration. The archbishop, however, was limited to one procession at SaintMartin, and he did not have the right to any procuration. 68

Saint-Martin's ritual involvement with Beaumont and SaintCosme was more intense that its involvement with Cormery. One aspect of that involvement occurred during the week after Easter, when the canons of the basilica went in procession to each of those two houses. On the occasion of those processions, the two houses owed procuration to the boy clerics and bell ringers of Saint-Martin: on the Monday after Easter, when the chapter visited Beaumont, the boy clerics ate a meal and the bell ringers received four deniers, four

66. Vaucelle, Collégiale de Saint-Martin, 257 n, 258 n; Bibliothèque Nationale, Collection Housseau, MS. 6, 2309, 23 I0 (I2I I); Cartulaire de Connery, 77, pp. 144-45 (I212); Tours, Bibliothèque Municipale, MS. 1294, p. I25 (1217); Bibliothèque Nationale, Collection Housseau, MS. 6, 2444. On Saint-Martin's right to seize the property, see Consuetudines ecclesiae beati Martini, I 38 .

67. Vaucelle, Collégiale de Saint-Martin, 253; Bibliothèque Nationale, Collection Baluze, MS. 77, fol. 428 .

68. Consuetudines ecclesiae beati Martini, 138, 148. 
loaves of bread, and a serving of wine; on Tuesday, at Saint-Cosme, the boys ate a meal and the bell ringers received four deniers, twelve loaves of bread, and a serving of wine.69

The episcopal symbolism of the canons' Easter visitations is striking. The week after Easter was a traditional time for bishops to make processions to religious institutions in their dioceses. Indeed, it was the archbishop of Tours's Easter visitation to Marmoutier that had given rise, in the eleventh century, to the exemption struggle between the monastery and the archbishop. The canons of Saint-Martin, who had also gained rights of exemption, demonstrated through their Easter procession and their right of procuration that their spiritual lordship over Beaumont and Saint-Cosme (two of the three houses over which they had full spiritual lordship) exceeded that of the archbishop over themselves. 70

Saint-Martin's practices during the Christmas season also involved a visit by the boy clerics to Beaumont, and again the visit entailed episcopal symbolism, though it was masked by the playfulness of traditional observances of the Christmas season. On the feasts of Saint Stephen (December 26), Saint John (December 27), and the Holy Innocents (December 28), the chapter of Saint-Martin, performed, as did a number of cathedral chapters, a series of ritual inversions. At vespers on the evening preceding each of the feasts, the canons sang the line from the Magnificat-"He has put down the powerful from their seats, and he has exalted the humble"-and the baculus of the cantor was passed to the members of one of the lower orders, who took over the canons' stalls for the next twenty-four hours. On Saint Stephen's Day the deacons took over; on Saint John's Day, the presbyters; and on Innocents', the boy clerics. ${ }^{71}$

69. Consuetudines ecclesiae beati Martini, 6I-62.

70. On the Easter visitation to Marmoutier, see chapter 2, notes $9 \mathrm{ff}$. Arnulf, the archbishop who made the visit to Marmoutier that ignited the violence at that abbey, also observed the custom of making an "episcopal station" at Saint-Julian each year on the second day after Easter: see Chartes de Saint-Julien, 12 (1034), p. 18. Saint-Julian never became an exempt house, and the archbishop continued to exercise rights of procuration there into the thirteenth century. In 1231, however, the monks gave some properties to the archbishop so that he would give up the right of procuration, including the right he had demanded when he visited the abbey each year on the vigil and feast of Saint Julian: see Chartes de Saint-Julien, 2:9-10, 12-17. It was also in 1231 that the monks of Cormery contested the archbishop's right of procuration at some of their priories and settled the matter with a financial exchange: see Cartulaire de Cormery, 84, pp. I53-54.

7I. At many houses the subdeacons took over the stalls and performed the rowdy feast of fools on New Year's Day. Saint-Martin's customal gives no evidence for this, though statutes from the late thirteenth century condemning the potential "scandal" and "shame" of the Christmas octave suggest that perhaps there was a feast of fools there: see Consuetudines ecclesiae beati Martini, 33-40 (parts of this passage were printed in De antiquis 
At Saint-Martin, as elsewhere, the feast of the Innocents was more elaborate than the feasts of Saints Stephen and John. Unlike the other lower orders, the boy clerics had their own bishop and cantor, who had been appointed on Saint Martin's feast of December 13.72 Moreover, the boys' festivities lasted more than just one day. On the day preceding the feast of the Innocents, the boys made a procession on horseback to the abbey of Beaumont, where they installed their bishop in his cathedra. Af ter he was installed, the boy bishop changed into silk vestments and made his first benediction over the nuns. Back at Saint-Martin, the boy bishop was raised in his cathedra at one of the doors of the basilica and carried to Martin's tomb, where a prayer was said and he made another benediction, over "the people." On Innocents' Day, when the boys took over the choir, their bishop read the seventh lession at matins and provided a meal for the other boys. On New Year's Day the boy bishop came last in a procession and made another benediction.

Although most of these arrangements for the boy bishop resemble those at cathedral chapters in other towns, the rituals at Saint-Martin had special significance, because the basilica was not a cathedral and because the boy bishop made a visitation to one of Saint-Martin's subject houses. The practice of electing or appointing a boy bishop usually occurred in cathedral chapters. When the boys of a cathedral took over the stalls of the choir, they inverted the usual hierarchy within their religious community by miming their elders and superiors-both the canons of the chapter and the bishop. 73 At SaintMartin, by contrast, the boys could invert only half of this hierarchy, by miming the canons. In appointing a boy bishop (he was not elected by the boys themselves), the senior members of the chapter of the basilica appropriated a symbol that did not belong to them.

The visitation of Saint-Martin's boy bishop to Beaumont was not unique-other boy bishops made visitations too. ${ }^{74}$ But in most cases

ecclesiae ritibus, bk. 4, chap. I3, reprint edition, vol. 3, cols. I07-8; "Quarta ecclesiae reformatio anno 1262" (Tours, Bibliothèque Municipale, MS. 1295, p. 557). For a general discussion of the ritual inversions of the Christmas octave, see Chambers, Medieval Stage, I:249-37I, 2:279-89. On the New Year's feast, see chapter 9 at notes $94 \mathrm{ff}$.

72. Consuetudines ecclesiae beati Martini, 27-30. For further analysis of the feast of December I3, see chapter 9 at notes $82 \mathrm{ff}$.

73. Chambers does cite examples of monasteries that elected boy bishops, but most of the evidence seems to be late: see Medieval Stage, I:360-361. For an excellent discussion of ritual inversion and misrule, see Davis, Society and Culture in Early Modern France, 97-1 23.

74. Thirteenth-century service book from Padua, published in Young, Drama of the Medieval Church, I:108. Chambers, Medieval Stage, I:347-48, citing Du Cange, Glossarium, s.v. "Kalendae," 4:48I-85, who quotes the fifteenth-century statutes of Toul. 
a visitation from the boy clerics of a cathedral chapter would have reinforced the claims of their bishop. This visitation, by contrast, served as a reminder that the chapter of Saint-Martin exercised certain ecclesiastical powers over Beaumont, powers that the archbishop of Tours was still trying to reclaim at the time Saint-Martin's customal was written. And the boys themselves were a direct reminder of the chapter's jurisdictional rights over the nunnery, since during the Easter visitation they were the major beneficiaries of the chapter's rights of procuration.

The most blatant aspect of the appropriation of episcopal symbolism for Saint-Martin was the way the ceremony of the boy bishop's installation paralleled the installation of the archbishop of Tours. On the day of his consecration, the archbishop was consecrated at the abbey of Saint-Julian, then he came to Saint-Martin in procession. He was led to the tomb of Saint Martin, and after a prayer was said he made his benediction over the people. Then the archbishop was led to the choir and placed in his cathedra, and the barons carried him back to the cathedral. 75

In the ceremony of the boy bishop's installation, the geographical relation between Beaumont and Saint-Martin paralleled the relation between Saint-Martin and the cathedral during the archbishop's installation. At Beaumont the boy bishop was raised up in his cathedra and made his first benediction, and from there he returned in procession to his mother church, or "cathedral." But one difference distinguished the boy's ceremony from that of the archbishop: the boy bishop of Saint-Martin had the right to visit Beaumont every year and to demand procuration along with the other boy clerics; the archbishop of Tours exhausted his rights to visit Saint-Martin on the day of his consecration.

It is possible that the boy bishop of Saint-Martin was installed at Beaumont precisely because that house was the only focus of continued disagreement between the archbishop and Saint-Martin at the time the customal was written. The sources do not indicate just when this custom arose, however, and there may have been other reasons for installing the boy bishop at Beaumont. Just as the custom of having the boy clerics receive a meal at Beaumont may have drawn out or symbolized the potential nurturing relationship between the women and the boys, the custom of installing the boy bishop there may have encouraged a playful encounter between the women and the children. 
In addition to engaging in rituals that symbolized their lordship over Cormery, Beaumont, Saint-Cosme, Saint-Venant, and SaintPierre-le-Puellier, the canons of Saint-Martin joined with these and other local houses in an exchange of ritual obligations that did not symbolize hierarchical dominance. Saint-Martin exchanged funeral obligations not only with the four subordinate houses that were close enough to be involved (all, that is, except Cormery), but also with the abbeys of Saint-Julian and Marmoutier and with the priory of SaintJacques-l'Orme-Robert. Saint-Julian and Marmoutier were not at all subordinate to Saint-Martin, and Saint-Jacques was a priory of SaintFlorent of Saumur, though it had once belonged to Saint-Martin, which still maintained some rights over it, including the right to stop there during the Easter procession to Beaumont. 76

Rogation processions, which took place during the week before Ascension Sunday, were also more representative of spiritual exchange than of domination. Saint-Julian and Beaumont exchanged rogation processions with Saint-Martin, the canons of Saint-Cosme made a rogation procession to Saint-Martin, and the monks of SaintJacques received a rogation procession. The canons of Saint-Venant and Saint-Pierre processed with the canons of Saint-Martin to SaintJulian. 77

In themselves, Saint-Martin's exchanges of rogations and funeral obligations with these seven houses did not undercut the authority or dignity of the archbishop of Tours. Indeed, the canons of Saint-Martin also attended the funerals of the archbishop; and Saint-Julian made rogation processions to the cathedral as well as to Saint-Martin. 78 Nevertheless, the cumulative effect of Saint-Martin's exchanges enhanced the dignity of the basilica. First, the visual impact of the ritual exchanges was uneven: whereas all the members of the seven proximate houses, except for the monks of Marmoutier, attended all the

76. Consuetudines ecclesiae beati Martini, 61, I 37-45. Saint-Martin's liturgical relations with Marmoutier originated with the charter of I I I 5 (see chapter 2 at note $4 \mathrm{I}$ ff.). Liturgical relations between Saint-Martin and Saint-Julian originated about 935 when Archbishop Theotolus refounded Saint-Julian. Theotolus established that Saint-Julian would celebrate matins at the basilica on Saint Martin's feast of November II. That practice was still observed when the customal was written: see Brevis historia Sancti Juliani Turonensis, 226; Consuetudines ecclesiae beati Martini, I45.

77. Consuetudines ecclesiae beati Martini, 67-68.

78. Concerning Saint-Martin's attendance at the funerals of archbishops, see Letter of Alexander III (1 I63), in Papsturkunden in Frankreich, n.s. 5, no. 123, p. 2 I5. Attendance at these funerals is not mentioned in Saint-Martin's customal. Concerning Saint-Julian's rogation processions, see Treasury of the Cathedral of Auxerre, MS. 6, fols. 74v (Monday af ter the fourth Sunday af ter the octave of Easter-procession to Saint-Martin); 75v (Tuesdayto Saint-Maurice); 77v (Wednesday-to a church of the convent's choice; the manuscript mentions certain liturgical arrangements if the monks choose to go to Saint-Loup, one of the abbey's possessions). 
funerals at Saint-Martin, the canons of the basilica attended only some of the funerals at the other houses. Thus, at the time of the funeral of one it its canons, Saint-Martin appeared as the hub of an impressive ecclesiastical community, one that included not only the houses subordinate to it, but also the monks of Saint-Julian and Saint-Jacques and at least some of the monks of Marmoutier. 79 The absence of the archbishop from these funerals enhanced the dignity of the basilica, since the archbishop could not present himself as a rival to its authority. The absence of the cathedral chapter was also notable, because it was the only major religious institution in the city and its immediate surroundings that was not represented at these funerals.

Although the funerals of the archbishops of Tours may have matched those of the canons of Saint-Martin in solemnity, the cathedral chapter could not match Saint-Martin's observances on the feast of the Major Litany, which took place on April 25, the feast of Saint Mark. On that day the nuns of Beaumont, the canons of SaintCosme, Saint-Venant, and Saint-Pierre, the monks of Saint-Julian and Saint-Jacques, and thirty of the monks of Marmoutier all made solemn processions to Saint-Martin. There each of the seven visiting communities took its place at a different door of the basilica, where they waited for the canons of the basilica to complete their own procession back from the church of Saint-Hilary. The eight religious communities then entered the basilica and took up positions at different altars. Once in place, they began to recite the litany-a general supplication for divine assistance and favor. 80

That seven neighboring religious communities converged on Saint-Martin during the Major Litany was significant. The canons of Saint-Martin were superimposing on their observation of the litany for April 25 the format of a litany that had been instituted by Pope Gregory the Great for the Lenten season of 590 , when Rome was besieged by a plague. Indeed, the conflation of the two litanies was explicit: in the foundation charter of the priory of Saint-Cosme (I092) the canons of Saint-Martin stipulated that as soon as the members of the new house numbered twelve or more they would be obliged to attend the "Gregorian litanies" at Saint-Martin. 81

79. Consuetudines ecclesiae beati Martini, I31-33, I37, 139-42, 145. The section on the burial of a canon of Saint-Martin mentions that the "monks" of Saint-Jacques came to the burial of every canon, but the section on Saint-Jacques mentions only that the prior of SaintJacques attended Saint-Martin's funerals. All the monks of Marmoutier attended the burial of one of Saint-Martin's priors; only ten came to the burial of an ordinary canon.

80. Consuetudines ecclesiae beati Martini, 69-7I.

81. "Si vero in duodecim et amplius numerus eorum pullulaverit deinceps Gregorianas rogationes in ecclesia B. Martini praesentiae suae frequentiae conventus ille decorabit" (Foundation Charter of Saint-Cosme, Tours, Bibliothèque Municipale, MS, 1295, p. 605). 
Gregory the Great had arranged that all the people of Rome, who were divided into seven groups according to their stations in life, were to process from seven different churches to the Church of SaintMary. 82 At Tours the seven religious communities that converged on the basilica from all directions also symbolically represented the entire urban area. In this representation of the city, the archbishop was once again noticeably absent, while Saint-Martin was clearly at the center. Whatever the archbishop attempted to do on this day, he was limited by the fact that all the major religious houses of the town and its immediate vicinity were obliged to participate in the litany at Saint-Martin. During the Major Litany, when the people appealed to God to bestow his grace and favor on their community, the basilica of Saint-Martin clearly represented the center of the community of Tours.

The appropriation of symbols of ecclesiastical power and dominance at Saint-Martin is representative, in part, of a concern with hierarchy and status that seems to have heightened about the time of Philip Augustus. Like the canons of Saint-Martin, the monks of Marmoutier, and most especially their abbots, began toward the end of the twelfth century to display the symbols of their status. Abbot Robert of Blois ( $1165-76$ ) built a separate bedchamber and chapel for himself and his successors; Abbot Hugh of Rochecorbon (1210-27) or one of his immediate predecessors assumed or attained the right to wear a bishop's miter. When the archbishop of Tours protested this practice, Hugh stopped wearing the miter, but he constructed a gate to the abbey that was known as the gate of the miter. Hugh also initiated the construction of Marmoutier's elaborate Gothic church, and his funeral was carried out "more solemnly" than those of earlier abbots. 83

Yet chronological developments alone do not account for the preoccupation at Saint-Martin with power and prestige. On the one hand, we can trace Saint-Martin's grandiose style back to the days of

82. For general discussions of the Major Litany and Gregory the Great's "septiform litany," see Cabrol, "Litanies," and Leclercq, "Marc (Procession de Saint)." See also Weiser, Handbook of Christian Feasts and Customs, 38-45. Weiser mentions that in some places rogation observances are still reminiscent of the septiform litany.

83. Hugh's brother was William de Roches, the seneschal of Anjou who turned against the Angevins and sided with Philip Augustus in I203. After 1204 royal registers listed Marmoutier as a royal abbey; however, John Baldwin found no royal charters of protection for Marmoutier, and it was not until I 259 that the king replaced the count of Anjou as the lay protector of Marmoutier: see Martène, Histoire de l'abbaye de Marmoutier, 2:188, 199200; Baldwin, Govermment of Philip Augustus, 233-39, 4I3, 445, 448; Chronicon abbatum Majoris monasterii, 321, 325-26; my Conclusion, at note 7. 
Odo of Cluny, if not before. 84 And on the other hand, the abbey of Marmoutier still retained, at the end of the twelfth century, spiritual concerns that distinguished its monks from the canons of the basilica. Guibert of Gembloux wrote his description of Marmoutier in I I 8 I or II 82, and the second legend about Odo of Blois and his wife Ermengard was probably written sometime in the second half of the twelfth century or the early years of the thirteenth. These sources indicate that suffrages for the dead, concern for the welfare of souls, penance, and a need to remain separate from the secular world remained central themes at Marmoutier at least until the very end of the twelfth century.

The abbey of Marmoutier ruled a large empire of priories and daughter houses, but for the monks, unlike the canons, domination was not an articulated theme, nor does domination appear in the records of the abbey's rituals. Indeed, most of Marmoutier's priories were inhabited by members of the mother abbey. Those monks did not undergo, as did the canons of Saint-Martin's priory of Léré, an entry ceremony that symbolized their separate and subordinate status. 85

On one level, the different purposes and corporate structures of Saint-Martin and Marmoutier help to explain the greater concern for status and power at the basilica. The canons, as I argued in the introduction to part 3, were much more openly entangled than were the monks of Marmoutier in the secular affairs and values of the world around them. They were also much more involved in the city of Tours itself-and this involvement led, especially after i i so, to frequent jurisdictional disputes between the basilica and the archbishop of Tours. Although the monks of Marmoutier also engaged in jurisdictional disputes with bishops and archbishops, those disputes were

84. Odo of Cluny, "Sermo de combustione basilicae beati Martini," PL I 33:736. Odo also told a story involving the ostentatious dress of an earlier generation of canons at SaintMartin: see John of Salerno, "Vita Sancti Odonis," 3:I, PL I 33:75. Odo's description of the earlier generation seems to be confirmed by a depiction of the canons of Saint-Martin in the Vivien Bible: Bibliothèque Nationale, MS. lat. I, fol. 423 (illumination depicting the presentation of the Bible to Charles the Bald).

85 . The customal of Marmoutier does not mention any processions with outside communities. This is somewhat misleading, since we know the monks went to Saint-Martin on April 25 and May I2: Antiquae consuetudines Majoris monasterii (see Source Appendix, I-F, on the date, sometime after I124). Evidence that the monks in the priories were considered monks of Marmoutier is in the following: De rebus gestis in Majori monasterio (see Source Appendix, I-D, on the date of the text-after I 137); Guibert, Abbot of Gembloux, "Epistola," 609 (the priors of the priories helped elect Marmoutier's new abbot); Letter of Urban III (I 1 86-87), in Papsturkunden in Frankreich, n.s. 5, no. 227, p. 321 ; Odo Rigaldus, Register of Eudes of Rouen (1248-69), 96, 102, 524. On the entry ceremony of the canons of Léré, see chapter 7 at note 55 . 
much more dispersed than were those of Saint-Martin. 86 The abbey did not enter into a new period of conflicts with the archbishop of Tours in the second half of the twelfth century.

In the face of local opposition to their dominance over the urban community of Tours, the canons became increasingly preoccupied with symbols of power and hierarchy. Just as they wished to maintain their domination over subordinate religious communities, the canons wished to maintain their domination over the lay community of Châteauneuf. Their struggles with that lay community are the subject of the next chapter.

86. Papsturkunden in Frankreich, n.s. S, nos. 27, 34, 69, 234, pp. 90-91, 98-99, I48-49, 327-28. 